\title{
Asian emissions in 2006 for the NASA INTEX-B mission
}

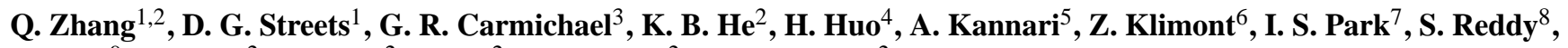

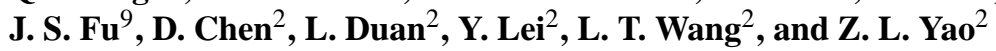 \\ ${ }^{1}$ Decision and Information Sciences Division, Argonne National Laboratory, Argonne, IL 60439, USA \\ ${ }^{2}$ Department of Environmental Science and Engineering, Tsinghua University, Beijing, China \\ ${ }^{3}$ Center for Global and Regional Environmental Research, University of Iowa, Iowa City, IA 52242, USA \\ ${ }^{4}$ Center for Transportation Research, Argonne National Laboratory, Argonne, IL 60439, USA \\ ${ }^{5}$ Independent Researcher, Tokyo, Japan \\ ${ }^{6}$ International Institute for Applied Systems Analysis, Laxenburg, Austria \\ ${ }^{7}$ Department of Environment, Hankuk University of Foreign Studies, Yongin-si, Republic of Korea \\ ${ }^{8}$ UK Met Office Hadley Centre, Exeter, Devon EX1 3PB, UK \\ ${ }^{9}$ Department of Civil \& Environmental Engineering, The University of Tennessee, Knoxville, TN 37996, USA
}

Received: 3 December 2008 - Published in Atmos. Chem. Phys. Discuss.: 9 February 2009

Revised: 7 July 2009 - Accepted: 21 July 2009 - Published: 29 July 2009

\begin{abstract}
A new inventory of air pollutant emissions in Asia in the year 2006 is developed to support the Intercontinental Chemical Transport Experiment-Phase B (INTEXB) funded by the National Aeronautics and Space Administration (NASA). Emissions are estimated for all major anthropogenic sources, excluding biomass burning. We estimate total Asian anthropogenic emissions in the year 2006 as follows: $47.1 \mathrm{Tg} \mathrm{SO}_{2}, 36.7 \mathrm{Tg} \mathrm{NO}_{\mathrm{x}}, 298.2 \mathrm{Tg} \mathrm{CO}$, 54.6 Tg NMVOC, 29.2 Tg PM $10,22.2 \mathrm{Tg} \mathrm{PM}_{2.5}, 2.97 \mathrm{Tg} \mathrm{BC}$, and $6.57 \mathrm{Tg}$ OC. We emphasize emissions from China because they dominate the Asia pollutant outflow to the Pacific and the increase of emissions from China since 2000 is of great concern. We have implemented a series of improved methodologies to gain a better understanding of emissions from China, including a detailed technologybased approach, a dynamic methodology representing rapid technology renewal, critical examination of energy statistics, and a new scheme of NMVOC speciation for modelready emissions. We estimate China's anthropogenic emissions in the year 2006 to be as follows: $31.0 \mathrm{Tg} \mathrm{SO}_{2}$, 20.8 $\mathrm{Tg} \mathrm{NO}_{\mathrm{x}}, 166.9 \mathrm{Tg} \mathrm{CO}, 23.2 \mathrm{Tg}$ NMVOC, $18.2 \mathrm{Tg} \mathrm{PM}_{10}$, 13.3 $\mathrm{Tg} \mathrm{PM}_{2.5}, 1.8 \mathrm{Tg} \mathrm{BC}$, and 3.2 Tg OC. We have also estimated 2001 emissions for China using the same methodology and found that all species show an increasing trend during 2001-2006: $36 \%$ increase for $\mathrm{SO}_{2}, 55 \%$ for $\mathrm{NO}_{\mathrm{x}}$, $18 \%$ for CO, $29 \%$ for $\mathrm{VOC}, 13 \%$ for $\mathrm{PM}_{10}$, and $14 \%$ for
\end{abstract}

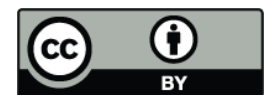

Correspondence to: Q. Zhang (zhangq@anl.gov)
$\mathrm{PM}_{2.5}, \mathrm{BC}$, and OC. Emissions are gridded at a resolution of $30 \mathrm{~min} \times 30 \mathrm{~min}$ and can be accessed at our web site (http://mic.greenresource.cn/intex-b2006).

\section{Introduction}

In 2006 the Intercontinental Chemical Transport Experiment-Phase B (INTEX-B) was conducted by the National Aeronautics and Space Administration (NASA). The INTEX-B mission was broadly designed to (a) improve our understanding of sources and sinks of environmentally important gases and aerosols through the constraints offered by atmospheric observations, and (b) understand the linkages between chemical source regions and the global atmosphere and the implications of human influence on climate and air quality (Singh et al., 2006). INTEX-B had a spectrum of measurement objectives for which individual aircraft flights were conducted in spring 2006. One of the specific objectives of INTEX-B was to quantify transport and evolution of Asian pollution to North America and assess its implications for regional air quality and climate (Singh et al., 2009). In this respect, INTEX-B had similar goals to a predecessor NASA mission in 2001, TRACE-P (Transport and Chemical Evolution over the Pacific) (Jacob et al., 2003), which studied outflow of pollution from the Asian continent and subsequent transport across the Pacific Ocean.

The processes of interest to INTEX-B operate at a variety of scales from local to global. To efficiently represent

Published by Copernicus Publications on behalf of the European Geosciences Union. 
these scales in a flight-planning context and in post-mission data analysis, multi-scale atmospheric models are used. One such modeling system used was developed at the University of Iowa (Carmichael et al., 2003a). This system includes global-scale inputs from the MOZART global chemical transport model (Horowitz et al., 2003), the intercontinental chemical tracer model CFORS (Uno et al., 2003a), and a nested regional chemical transport model, STEM-2K3 (Tang et al., 2004). In order to drive such a modeling system, emission inventories are necessary. For the TRACE-P mission a detailed emission inventory was prepared for the year 2000 (Streets et al., 2003a, b) that has received widespread application both within the TRACE-P mission and in subsequent Asian modeling studies. To support INTEX-B it has been necessary to update the TRACE-P inventory to reflect the extremely rapid economic growth in Asia since 2001. In addition, new work was necessary to refine the temporal and spatial resolution of the emission data and to add important new species, source types, and geographical regions. This new inventory for 2006 enables a more accurate representation of Asian outflow, cross-Pacific transport, and North American inflow to be provided for INTEX-B studies.

During the past several years, China's atmospheric emissions are known to have increased markedly, following the dramatic growth of its economy and energy use. The general methodology used to build the new Asian regional emission inventory has been described in Streets et al. (2003a, b). Using the same general approach, we have implemented an improved technology-based methodology, in order to be able to reflect the types of technology presently operating in China. We also implemented a new anthropogenic PM emission model (Zhang et al., 2006) to calculate primary PM emissions, including $\mathrm{PM}_{10}$ and $\mathrm{PM}_{2.5}$, which the TRACE-P inventory did not address.

The key elements of the INTEX-B inventory are listed in Table 1. The domain covers 22 countries and regions in Asia and stretches from Pakistan in the West to Japan in the East and from Indonesia in the South to Mongolia in the North (Fig. 1). In this paper we emphasize emissions from China because they dominate the Asia pollutant outflow to the Pacific and the increase of emissions from China since 2000 is of great concern.

Emissions are estimated for eight major chemical species: $\mathrm{SO}_{2}, \mathrm{NO}_{\mathrm{x}}, \mathrm{CO}$, nonmethane volatile organic compounds (NMVOC), particulate matter with diameters less than or equal to $10 \mu \mathrm{m}\left(\mathrm{PM}_{10}\right)$, particulate matter with diameters less than or equal to $2.5 \mu \mathrm{m}\left(\mathrm{PM}_{2.5}\right)$, black carbon aerosol (BC), and organic carbon aerosol (OC). Emissions of methane $\left(\mathrm{CH}_{4}\right)$ and ammonia $\left(\mathrm{NH}_{3}\right)$ were not updated from TRACE-P in this work, because they have not changed much since 2000, as confirmed by the REAS inventory (Ohara et al., 2007). In addition, $\mathrm{CH}_{4}$ and $\mathrm{NH}_{3}$ were low priorities of the INTEX-B mission (Singh et al., 2006). NMVOC emissions are speciated into five categories corresponding to five different chemical mechanisms (CBIV, CB05, RADM2,

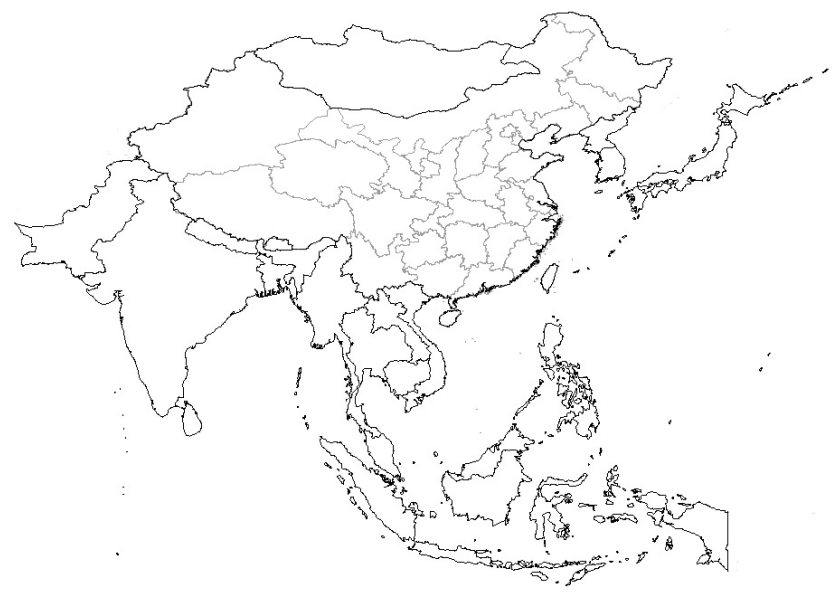

Fig. 1. Definition of the inventory domain.

SAPRC99, and SAPRC07); this aspect of the inventory is described in a separate paper (Zhang et al., 2009).

Only anthropogenic emissions are estimated in this work. Biomass burning emissions were included in the TRACE-P inventory, but since then a number of new high-resolution biomass burning inventories have been developed using satellite observations of burning (e.g., Duncan et al., 2003; van der Werf et al., 2006; Randerson et al., 2007) that offer superior representation of emissions for specific years. TRACE-P biomass burning emissions can still be used by modelers interested in obtaining a typical representation of Asian biomass burning. The detailed emission calculations for the 2006 INTEX-B inventory are aggregated into four source categories: electricity generation, industry, residential, and transportation.

Emission estimates in this work are specifically for the year 2006, because this inventory was prepared for the INTEX-B field campaign undertaken in spring 2006, and it was intended to reflect the actual magnitude of emissions during that period as closely as possible. However, when construction of the inventory took place in 2006 and 2007, most of the necessary statistics for Asian countries were only available for 2004/2005 and very few for the year 2006. Thus this inventory is built on a mixture of trend extrapolations from 2004/2005 and actual 2006 data.

Section 2 documents the methodology used in this work. The estimation of emissions from such a wide variety of species and regions cannot be described in complete detail due to space limitations. However, we give a general overview of methods, data, and data sources for this inventory and highlight the major advances from the previous TRACE-P inventory.

Emission estimates for the year 2006 are presented in Sect. 3. It should be noted that this 2006 INTEX-B inventory (I06) and the 2000 TRACE-P inventory (T00) are not directly comparable, because several important methodological changes were made at the same time to improve the 
Table 1. Summary of the INTEX-B Asia emission inventory dataset.

\begin{tabular}{ll}
\hline Item & Description \\
\hline Domain & 22 countries and regions in Asia, see Fig. 1 \\
Species & $\mathrm{SO}_{2}, \mathrm{NO}_{\mathrm{x}}, \mathrm{CO}, \mathrm{NMVOC}, \mathrm{PM}_{10}, \mathrm{PM}_{2.5}, \mathrm{BC}, \mathrm{OC}$ \\
VOC speciation & by mechanism: CB04, CB05, RADM2, SAPRC99, SAPRC07 \\
Sectors & power plants, industry, residential, transportation \\
Representing Year & 2006 \\
Spatial resolution & 30 min $\times 30$ min \\
Seasonality & monthly \\
Data availability & available online at http://mic.greenresource.cn/intex-b2006 \\
& http://www.cgrer.uiowa.edu/EMISSION_DATA_new/index_16.html \\
\hline
\end{tabular}

representation of actual emissions. In Sect. 3.1, we revisit China's emissions for 2001 (R01), the year of the TRACE-P campaign, using our new methodology. Then the differences between R01 and T00 reflect the improvements and corrections made to the T00 inventory, and the changes between I06 and R01 represent actual growth in emissions in China between 2001 and 2006. Asian emission estimates by country are presented in Sect. 3.2.

Emissions are initially calculated by country (by province for China) on an annual basis. However, emissions from some species have strong seasonal variations associated with such activities as fossil-fuel and biofuel use for home heating in winter. The seasonality in emissions is important when comparing emissions with time-specific field measurements. For this reason, we have also developed monthly emissions using a variety of methods, which are discussed in Sect. 3.3. Atmospheric models also require gridded emissions as inputs, rather than regional emission totals. Section 3.4 presents the spatial distribution of emissions at a resolution of $30 \mathrm{~min} \times 30 \mathrm{~min}$, using various spatial surrogates. All regional summaries and gridded data can be downloaded from several websites, as described in Sect. 3.5.

In the discussion section (Sect. 4), we compare our estimates with other inventory studies. Top-down constraints on emissions also provide valuable clues for verifying emission estimates, which have been successfully used in the revision and improvement of China's CO emission inventory after the TRACE-P campaign (Streets et al., 2006). Therefore, in Sect. 4 we also compare our inventory with various top-down constraints, e.g., forward modeling, inverse modeling, and constraints from satellite and in-situ observations, and try to explain any discrepancies between inventories and top-down studies. In Sect. 4.3, we discuss the major uncertainties in this inventory and the future efforts that are needed to develop an even better understanding of Asian emissions. Finally, in Sect. 4.4, we summarize the relevant studies that have used this inventory and the implications for the present inventory.

\section{Methodology}

Figure 2 shows the general methodology for this inventory. We assemble the new Asian emission inventory according to the following steps. First, we implement a series of improved, technology-based methodologies to develop a new emission inventory for China. The key aspects of these improvements are documented in Sect. 2.1. This same approach was used for the development of the improved CO inventory (Streets et al., 2006), the first primary particulate emission inventory (Zhang et al., 2006, 2007a), and a new $\mathrm{NO}_{\mathrm{x}}$ emission trend for China (Zhang et al., 2007b). We update China's emissions to the year 2006 with these new methodologies. Second, we update emissions for other Asian countries to the year 2006 following the methodology of the TRACE$\mathrm{P}$ inventory but using the most recent statistics available. Third, we incorporate the best available datasets for some selected regions, where good national inventories exist that are thought to be more accurate than the TRACE-P inventory, being built on local data sources and local knowledge. In this respect we have incorporated the following external data sources into the INTEX-B inventory: $\mathrm{SO}_{2}$ and aerosol inventories for India (Reddy and Venkataraman, 2002a, b); a $1 \mathrm{~km} \times 1 \mathrm{~km}$ high-resolution emission inventory for Japan (Kannari et al., 2007); a South Korean inventory from the National Institute of Environmental Research of Korea (NIER, 2005, 2008), and a Taiwan inventory from the Taiwan Environmental Protection Administration (Fu et al., 2009). These override the TRACE-P updates. Finally, we check for consistency among the different datasets, choose the appropriate precision for the final product, and finally export the dataset over the whole of Asia with a uniform data format.

In this section, we focus on the new methodology for China's emission estimates, because it is the major revision of the inventory compared with the TRACE-P inventory and the change that has the single largest impact on total Asian emissions. 


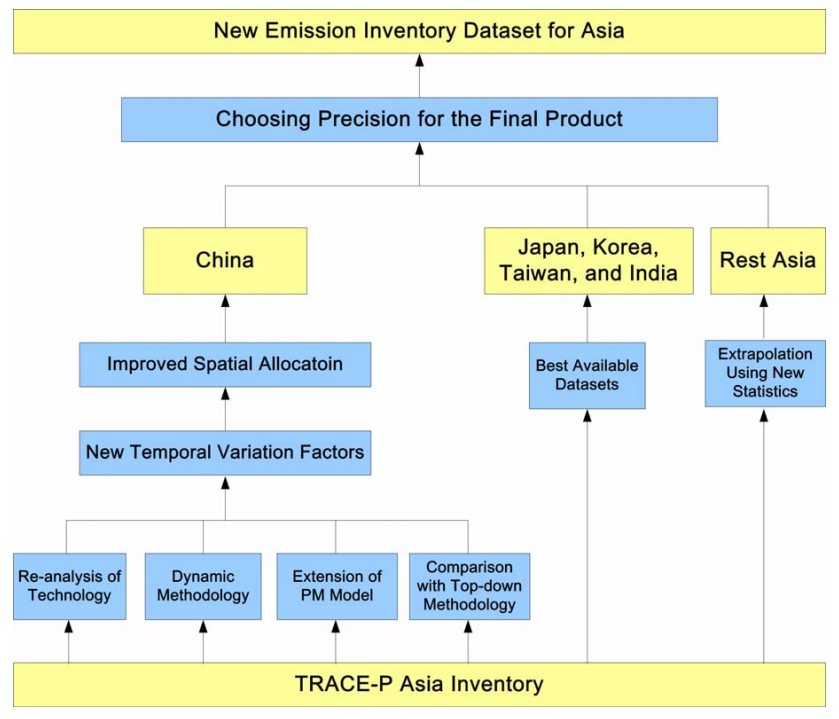

Fig. 2. Schematic methodology for the development of the INTEXB Asia emission inventory.

The emissions of a particular species are estimated by the following equation:

$E_{i}=\sum_{j} \sum_{k} A_{i, j, k}\left[\sum_{m} X_{i, j, k, m} E F_{j, k, m}\right]$

For a given technology $m$, the net emission factor is estimated as follows:

$E F=E F_{\mathrm{RAW}} \sum_{n} C_{n}\left(1-\eta_{n}\right)$

where $i$ represents the province (municipality, autonomous region); $j$ represents the economic sector; $k$ represents the fuel or product type; $m$ represents the technology type for combustion and industrial process; $n$ represents a specific control technology; $A$ represents the activity rate, such as fuel consumption or material production; $X$ is the fraction of fuel or production for a sector that is consumed by a specific technology; $E F$ is the net emission factor; $E F_{\mathrm{RAW}}$ is the unabated emission factor; $C_{n}$ is the penetration of control technology $n$; and $\eta_{n}$, is the removal efficiency of control technology $n$.

\subsection{Revision and improvement of the TRACE-P inventory for China}

In this work, we have researched many aspects of the China part of the TRACE-P inventory for possible improvements by critical retrospective examination of how the original inventory was constructed and how well it performed in the various modeling and assessment projects in which it was used. We note the following major improvements thought to be necessary: a) A detailed technology-based approach. The final release rates of pollutants greatly depend on combustion efficiency, control equipment, and operating conditions. Thus, a detailed source classification by technology level is critical for obtaining reliable emission estimates. In the TRACE-P inventory, emitting sources were usually classified at the economic sector level, say, power generation, industry, or residential, and an average emission factor was applied for the whole sector. However, in a rapidly developing country like China, both advanced and old-fashioned technologies coexist in the marketplace, which can have very different levels of emissions. For example, the $\mathrm{CO}$ emission factors of industrial combustion devices can vary from $2 \mathrm{~g} / \mathrm{kg}$ for large, modern coal-fired boilers to $156 \mathrm{~g} / \mathrm{kg}$ for old kilns, leading to an average emission factor of $85.7 \mathrm{~g} / \mathrm{kg}$ for the industrial combustion sector as a whole, more than a factor of two greater than the value used in the TRACE-P estimates. We have successfully applied such a technology-based methodology to improve the CO emission inventory for China (Streets et al., 2006), and we expand the method to all species in this work.

b) Re-examination of energy statistics. Data inconsistency in Chinese energy statistics downgrades the accuracy of emission inventories that largely rely on statistics (Akimoto et al., 2006). In recent work on China's $\mathrm{NO}_{\mathrm{x}}$ emission trend (Zhang et al., 2007b), we critically evaluated the quality and reliability of current Chinese energy statistics and used several approaches for better representation of the real-world situation in China when compiling activity data. These approaches include: using coal consumption data in the provincial energy balance tables of the China Energy Statistical Yearbooks (CESY) to reflect the actual coal production and consumption; using diesel consumption data in the national energy balance table of CESY to avoid the "lost diesel" from inter-province transportation; and a model approach for fuel consumption for each vehicle type, as these data are not available in statistics. We followed these procedures in this work. For more details, the reader is referred to Sects. 3.2, 3.3, and 4.5 of Zhang et al. (2007b).

c) A dynamic methodology representing rapid technology renewal. Potentially rapid changes of emission factors should be considered when evaluating emission trends in developing countries. In China, new technologies are constantly coming into the marketplace - sometimes to replace older technologies, sometimes not - causing rapid changes in net emission rates in just a few years. Therefore, it is necessary to develop a representation of the dynamic change in net emission factors driven by the technology renewal process, rather than simply to use year-by-year activity data with fixed emission factors. In this study, we use this strategy when revisiting the TRACE-P emissions and comparing with 2006 emissions, to get a more reliable picture of emission trends. In Sect. 2.3, we summarize the change of emission factors from 2001 to 2006 due to technology renewal and discuss the resulting emission changes in Sect. 3.1.2. 
d) A size-fractioned primary PM emission inventory. The emissions of two aerosol species, BC and OC, were estimated in the TRACE-P inventory, but primary $\mathrm{PM}_{10}$ and $\mathrm{PM}_{2.5}$ emissions were not reported. In this paper, we present a comprehensive estimation of primary particulate emissions in China by size distribution and major components, using a technology-based approach described in Zhang et al. (2006, 2007a). With this approach, we are able to classify particulate emissions into three size ranges, total suspended particulates (TSP), $\mathrm{PM}_{10}$, and $\mathrm{PM}_{2.5}$ (the latter two are reported in this paper), and also identify the contributions of $\mathrm{BC}$ and OC.

e) A new scheme of NMVOC speciation for model-ready emissions. NMVOCs differ significantly in their effects on ozone formation, and these differences need to be represented appropriately in the air quality models used to predict the effects of changes of emissions on formation of ozone. This requires appropriate methods to specify the chemical composition of the many types of NMVOCs that are emitted and appropriate methods to represent these compounds in the models. In the TRACE-P inventory, NMVOC emissions were speciated into 19 categories based on chemical reactivity and functional groups. However, these emissions are usually not ready for model use: atmospheric modelers have to map those 19 categories into the categories that their models use. This conversion process is not accurate and can introduce unpredictable uncertainties.

In this work, we improve the NMVOC speciation methodology toward an atmospheric-model-ready dataset by using a step-by-step VOC speciation assignment process. Emissions for individual VOC species are calculated by applying a state-of-the-art source profile database (e.g., Liu et al., 2008) to each source category. Then we lump individual NMVOC emissions to emitted species in different chemistry mechanisms. Up to now, we have developed model-ready emissions for five mechanisms: CBIV, CB05, RADM2, SAPRC99, and SAPRC07. The detailed description of this methodology and the results are presented in a separate paper (Zhang et al., 2009).

f) Comparison with top-down constraints. Last, but not least, top-down analytical tools applied to the interpretation of emissions provide valuable constraints to improve bottomup emission inventories such as this one. Such techniques include forward modeling and inverse modeling using in situ and satellite observations, or even simply using observation data without models. In the years after the TRACE-P mission, these techniques have become widely used to constrain Asian emissions against a priori estimates. The results of these analyses sometimes support the inventory, while more often they raise questions about the accuracy of the inventory. In Sects. 4.1 and 4.2 of this paper, we present an intensive review of these analyses, discuss the existing discrepancies, and attempt to find a direction to reconcile the inventory in light of these findings.

\subsection{Activity rates}

\subsubsection{China}

We derive activity data for China for the years 2001 and 2006 from a wide variety of sources, with a critical examination of the data reliability. Fuel consumption in stationary combustion sources by sector and by province ( $A$ in Eq. 1) is derived from the provincial energy balance tables of the CESY (National Bureau of Statistics, 2004, 2007a), with the exception of diesel consumption. We use diesel consumption values in the national energy table of CESY and then derive shares from the provincial tables (see explanation in item $b$ of Sect. 2.1). Industrial production by products and by province is derived from other governmental statistics (National Bureau of Statistics, 2002a, b, 2006, 2007b; AISIC, 2002, 2006). The methods for determining activity levels of non-energy sources for NMVOC are the same as in previous analyses (Klimont et al., 2002). The distributions of the combustion technology in each sector and the processing technology in each industrial product ( $X$ in Eq. 1) are generally not available from government statistics. In this work, these data were collected from a wide range of unpublished statistics by various industrial association and technology reports. The data sources of key emitting sources in China are summarized in Table 2.

When this inventory was developed in 2006 and 2007, most of the available statistics for Chinese provinces were for 2004/2005 and very few for the year 2006. We therefore extrapolated activity data to the year 2006 based on various fast-track statistics that are published monthly (Beijing Huatong Market Information Co. Ltd., various issues, 2006; China Statistical Information and Consultancy Center, various issues, 2006).

We classify vehicles into light-duty gasoline vehicles (LDGV), light-duty gasoline trucks up to $6000 \mathrm{lb}$ gross vehicle weight (LDGT1), light-duty gasoline trucks with gross vehicle weight 6001-8500 lb (LDGT2), light-duty diesel trucks (LDDT), heavy-duty gasoline vehicles (HDGV), heavy-duty diesel vehicles (HDDV), and motorcycles, corresponding to the classification method in the US EPA's MOBILE emission factor model. It is not possible to derive the fuel consumption for each vehicle type from CESY. As an alternative approach we estimate fuel consumption from vehicle population, annual average vehicle mileage traveled, and fuel economy for each vehicle type. This method has been documented in our previous work (Streets et al., 2006), and the full details of the model used and the methodological approach are described elsewhere (He et al., 2005).

\subsubsection{Other Asian countries}

We follow the approach of the TRACE-P inventory for activity rates for other Asian countries but use International Energy Agency (IEA) energy statistics (IEA, 2006) for energy 
Table 2. The data sources of key emitting sources in China.

\begin{tabular}{lll}
\hline Emitting Sources & Activity Data & Technology Distribution \\
\hline Power plants & China Energy Statistical Yearbook & Ministry of Environmental Protection of China, unpublished data \\
Industry boilers & China Energy Statistical Yearbook & China Mechanical Industry Yearbook \\
Residential combustion & China Energy Statistical Yearbook & N/A \\
Coke production & China Energy Statistical Yearbook & National Bureau of Statistics, unpublished data \\
Cement production & China Statistical Yearbook & Chinese Cement Association, unpublished data \\
Iron \& Steel production & China Statistical Yearbook & China Iron and Steel Statistics \\
Vehicles & China Automotive Industry Yearbook & Using a modeling approach documented in He et al. (2005) \\
\hline
\end{tabular}

use by fuel type, sector, and country instead of the RAINSASIA database. Activity data for the year 2006 are extrapolated from 2000-2004 IEA energy data using the average growth rate during 2000-2004. Technology distributions within each sector were obtained from the IMAGE 2.2 database (RIVM, 2001). Industrial production by product and country is derived from United States Geological Survey statistics (USGS, 2006) and also extrapolated to the year 2006. The methods for determining activity levels of nonenergy sources of NMVOC are the same as in previous work (Klimont et al., 2001).

\subsection{Emission factors}

Emission factors for the years 2001 and 2006 for China are developed using our dynamic, technology-based methodology. We assume that the emission rate is fixed over the years for a given combustion/process technology ( $m$ in Eq. 1) and control technology ( $n$ in Eq. 2). Development of emission factors by technology has been documented in our previous work (Klimont et al., 2002; Streets et al., 2006; Zhang et al., 2006, 2007a, b). However, for a fast developing country like China, new technologies are constantly coming into the marketplace, causing rapid changes in the penetration of technologies ( $X$ in Eq. 1 and $C_{n}$ in Eq. 2) and therefore rapid changes in net emission factors for a fuel/product in a specific sector. We estimate year-by-year changes in $X$ and $C_{n}$, where possible.

In some cases, we use the same emission factors for the years 2001 and 2006. For example, VOC emission factors of various industrial processes are the same for the years 2001 and 2006, because we are not aware of any VOC capture technologies being used for those processes. We also use fixed emission factors for many small combustion devices like coal and biofuel stoves because there is no efficient way to control their emissions. But for most sectors, net emission factors were fundamentally changed to reflect the dramatic economic growth and dynamic technology penetration. Table 3 summarizes the significant changes of emission factors between 2006 and 2001 in China.
Environmental legislation is always an important determinant of emission factors. For example, the Chinese government has announced an ambitious plan to reduce national $\mathrm{SO}_{2}$ emissions by $10 \%$ in 2010 compared with 2005 . To achieve this goal, flue-gas desulfurization (FGD) devices are now being widely installed in coal-fired power plants. From 2001 to 2006, FGD penetration increased from $3 \%$ to $30 \%$, causing a $15 \%$ decrease in the average $\mathrm{SO}_{2}$ emission factor for coal-fired power plants (see Fig. 3a). Likewise, during the same period, net $\mathrm{PM}_{2.5}$ emission factors in power plants declined from $2.0 \mathrm{~g} / \mathrm{kg}$ coal to $1.2 \mathrm{~g} / \mathrm{kg}$ coal, a reduction of $40 \%$. This reduction is largely attributed to a new, strengthened PM emission standard for power plants published in 2003 (SEPA, 2003).

A series of emission standards was implemented for new vehicles in 1999, as shown in Table 4. Since then, new vehicles with advanced emission-control technologies began to join the fleet and replace old ones. In 2006, $60 \%$ of on-road gasoline vehicles could meet EURO II or EURO III emission standards, increased from $1 \%$ in 2001. As a result, from 2001 to 2006, the average emission factors of gasoline vehicles decreased by $23 \%$ for $\mathrm{NO}_{\mathrm{x}}, 54 \%$ for $\mathrm{CO}$, and $36 \%$ for VOC (Fig. 3b).

Technology improvement is another important driving force. Since the year 2000, the market share of large boilers (capacity $>300 \mathrm{MW}$ ) has increased rapidly in power plants. Those boilers were usually equipped with low- $\mathrm{NO}_{\mathrm{x}}$ burner technology (LNB) and hence have lower $\mathrm{NO}_{\mathrm{x}}$ emission factors than the older, smaller plants. This transition has cut the average $\mathrm{NO}_{\mathrm{x}}$ emission factor of the ensemble of plants by about $10 \%$ from 2001 to 2006 (Fig. 3a). Technology renewal in China's cement plants has also caused a significant change in the net emission factor. There are two main types of kilns in China's cement plants: shaft kilns and rotary kilns. Shaft kilns have higher $\mathrm{CO}$ emission factors but lower $\mathrm{NO}_{\mathrm{x}}$ emission factors than rotary kilns, because the high concentration of $\mathrm{CO}$ in the combustion gas produces a reducing atmosphere that restrains the formation of $\mathrm{NO}_{\mathrm{x}}$. In recent years, shaft kilns have been largely replaced by rotary kilns. From 2001 to 2006, the market share of rotary kilns increased from 29\% to 50\% (Chinese Cement Association, 


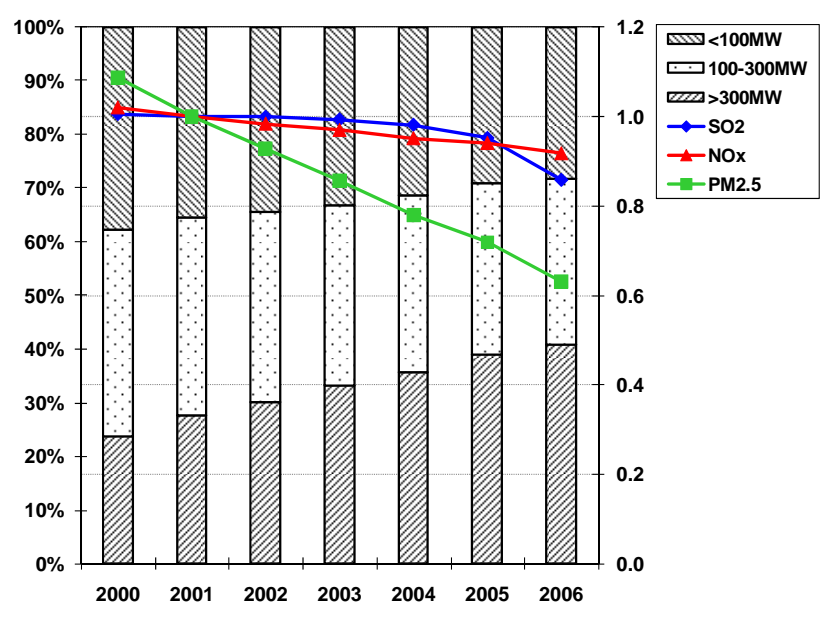

a) coal-fired power plants

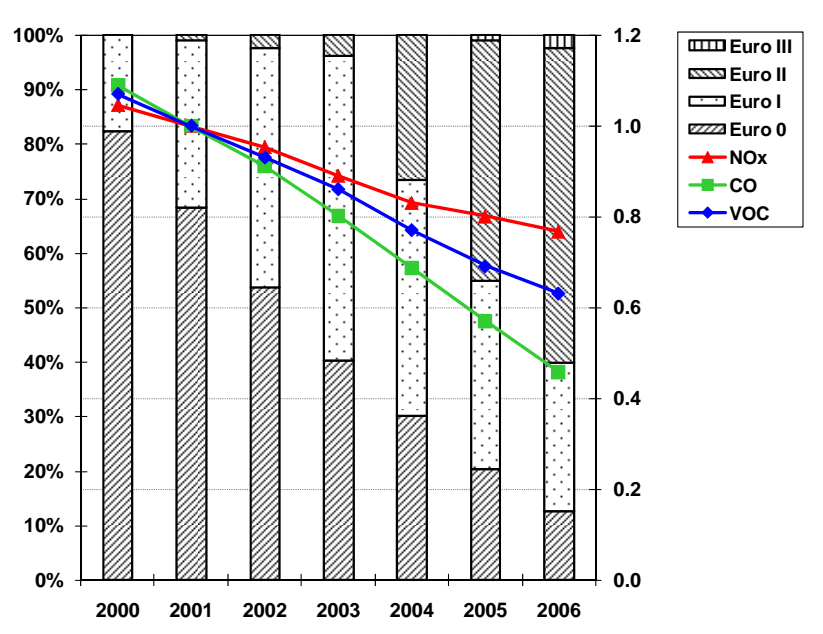

b) gasoline vehicles

Fig. 3. Technology renewal and average emission factors for China. Bars represent the percentage of each technology: (a) share of power units with different boiler size; (b) share of gasoline vehicles with different stages of control technologies. Line: trends of average emission factors. All data are normalized to the year 2001.

unpublished data, 2007), leading to a $25 \%$ decrease in the average $\mathrm{CO}$ emission factor but a $35 \%$ increase in the average $\mathrm{NO}_{\mathrm{x}}$ emission factor of China's cement plants.

For other Asian countries, we have generally used the same emission factors as in the TRACE-P inventory. An exception is for vehicle emissions. Emission factors for vehicles were derived using the MOBILE model, by integrating the varying stages of emission restrictions in recent years, to reflect the changes of emission factors due to implementation of emission standards.

\section{Results}

\subsection{China emissions}

\subsubsection{Revisiting 2001 emissions: learning from methodology improvements}

With the improved methodology described above, we estimate China's anthropogenic emissions in the year 2001 as follows: $22.9 \mathrm{Tg} \mathrm{SO}_{2}, \quad 13.4 \mathrm{Tg} \mathrm{NO}_{\mathrm{x}}, 141.6 \mathrm{Tg} \mathrm{CO}$, 18.1 Tg NMVOC, $16.1 \mathrm{Tg} \mathrm{PM}_{10}, 11.7 \mathrm{Tg} \mathrm{PM}_{2.5}, 1.6 \mathrm{Tg} \mathrm{BC}$, and $2.8 \mathrm{Tg}$ OC. Table 5 summarizes the 2001 emission estimates by species and by sector and presents the difference between this 2001 inventory (R01) and the TRACE-P inventory for the year 2000 (T00). R01 estimates generally show a significant increase compared with $\mathrm{T} 00$, ranging from a $6 \%$ increase for $\mathrm{OC}$ to $70 \%$ for $\mathrm{BC}$. Because the actual emission increases from 2000 to 2001 were not so significant (e.g., $5 \%$ increase for $\mathrm{NO}_{\mathrm{x}}$ ), these differences between $\mathrm{R} 01$ and $\mathrm{T} 00$ can be mainly attributed to the improvements of methodology.

The reasons for these differences vary among sectors and species. The most important reason is that R01 uses a technology-based approach that can identify emissions from specific types of technology. For example, industrial CO emissions in R01 are higher than in T00 by a factor of three, contributing significantly to the difference of $\mathrm{CO}$ emissions between T00 and R01. Compared with T00, R01 has a much more detailed categorization of sources in the industrial sector, which allows the identification of important $\mathrm{CO}$ emitting sources from specific industries such as cement kilns and brick kilns, which were missing in T00 (Streets et al., 2006). The situation is similar for other species. In R01, traditional brick kilns and coking production are identified as two important individual sources for $\mathrm{BC}$ and $\mathrm{OC}$ emissions. Using emission factors from Bond et al. (2004), BC emissions from traditional brick kilns and coking processes for the year 2001 are estimated to be $241 \mathrm{Gg}$ and $183 \mathrm{Gg}$, respectively, accounting for $15.1 \%$ and $11.5 \%$ of total anthropogenic emissions. These two important carbonaceous aerosol sources were missing in T00.

Another important reason is that R01 includes more emitting sources than T00. For example, we include off-road diesel emissions in R01 in the transportation sector. As a result, although emissions for on-road vehicles are similar in $\mathrm{R} 01$ and $\mathrm{T} 00, \mathrm{NO}_{\mathrm{x}}, \mathrm{VOC}, \mathrm{BC}$ and $\mathrm{OC}$ emissions from the transportation sector as a whole in R01 are higher by $37 \%$, $23 \%, 140 \%$, and $35 \%$, respectively, than in T00 due to the inclusion of off-road vehicle emissions. R01 also has higher VOC, BC, and OC emissions for power plants than T00, which can be attributed to the inclusion of oil-fired power plant emissions in $\mathrm{R} 01$, but not in $\mathrm{T} 00$. And, $\mathrm{NO}_{\mathrm{x}}$ emissions from the residential sector in R01 are 37\% higher than in T00, because R01 includes emissions from liquid fuels. 
Table 3. Changes of emission factors between 2006 and 2001.

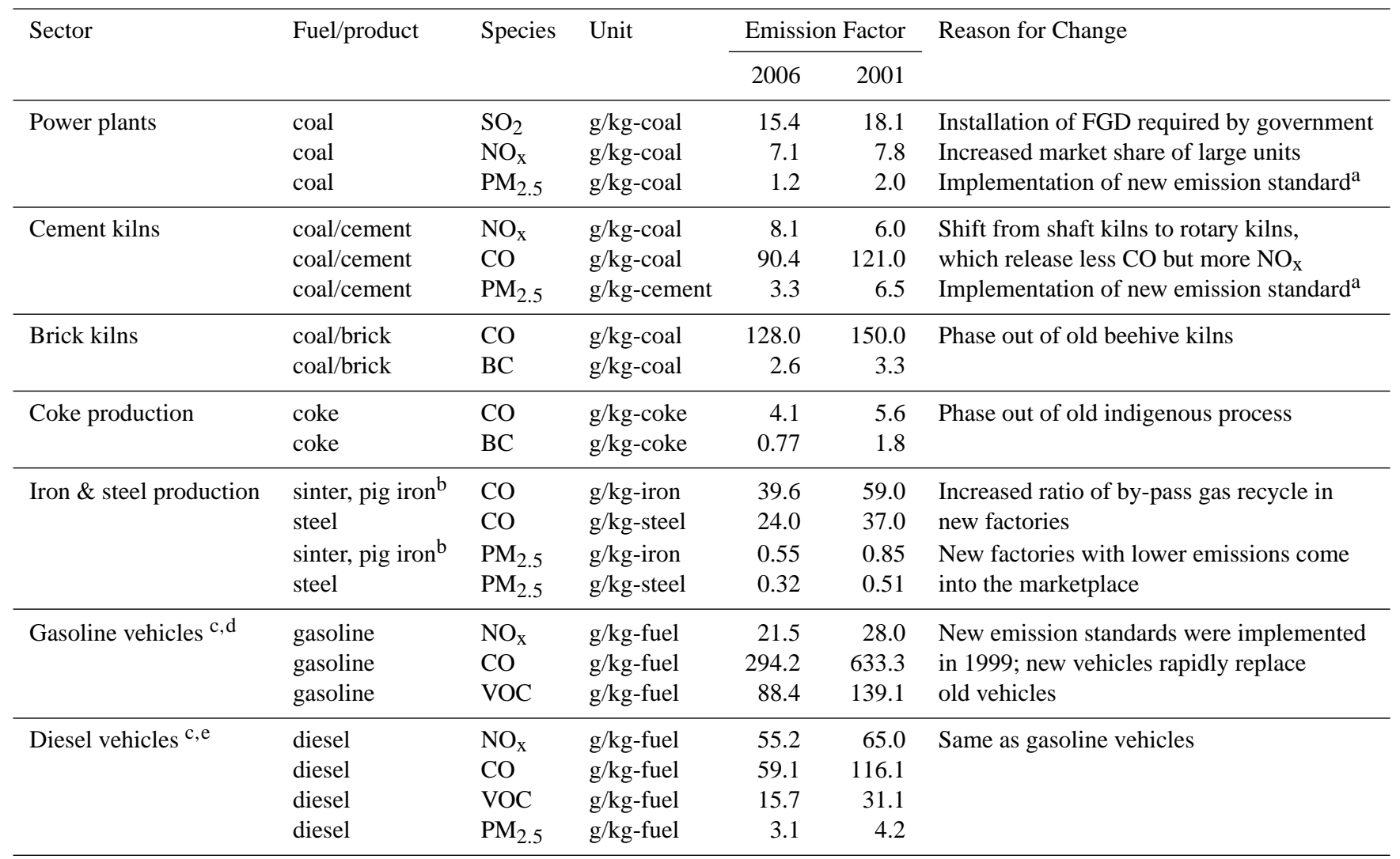

a SEPA $(2003,2004){ }^{b}$ emission factors are given for the sum of sintering processes and pig iron production; ${ }^{\mathrm{c}}$ emission factors were calculated by MOBILE model in $\mathrm{g} / \mathrm{km}$, then converted to $\mathrm{g} / \mathrm{kg}$-fuel according to the fleet average fuel economy data of He et al. (2005);

$\mathrm{d}$ emission factors were calculated for LDGV (car), LDGT1, LDGT2, and HDGV separately. Here average emission factors are presented;

$\mathrm{e}$ emission factors were calculated for LDDT and HDDT separately. Here average emission factors are presented.

Table 4. Implementation schedule of new vehicle emission standards in China.

\begin{tabular}{lcccc}
\hline & Euro I & Euro II & Euro III & Euro IV \\
\hline Gasoline (Beijing) & 1999 & 2003 & 2006 & 2008 \\
Gasoline (national) & 2001 & 2004 & 2007 & 2010 \\
Diesel (national) & 2001 & 2004 & $2008^{\mathrm{a}}$ & 2010 \\
\hline
\end{tabular}

a initially scheduled for 2007 , but postponed to 2008 .

Different data sources can also lead to different results. For the power plant sector, $\mathrm{SO}_{2}$ and $\mathrm{NO}_{\mathrm{x}}$ emissions in $\mathrm{R} 01$ are both $22 \%$ higher than in T00. This is mainly because the coal consumption data used in R01 are actual statistical data from CESY, while the data used in T00 were extrapolated from 1995 data, which was lower than in the actual reported statistics. $\mathrm{SO}_{2}$ emissions for transportation in $\mathrm{R} 01$ are $82 \%$ lower than in T00 because we use lower sulfur contents for transportation fuels - though the contribution of the transportation sector to total $\mathrm{SO}_{2}$ emissions is small.

\subsubsection{6 emissions: emission growth and driving forces}

We estimate China's anthropogenic emissions in the year 2006 to be as follows: $31.0 \mathrm{Tg} \mathrm{SO}_{2}, \quad 20.8 \mathrm{Tg}$ $\mathrm{NO}_{\mathrm{x}}, \quad$ 166.9 Tg CO, 23.2 Tg NMVOC, $18.2 \mathrm{Tg} \mathrm{PM}_{10}$, 13.3 $\mathrm{Tg} \mathrm{PM} 2.5,1.8 \mathrm{Tg} \mathrm{BC}$, and 3.2 Tg OC. Table 6 presents the 2006 emission estimates and Fig. 4 shows the emission increase from 2001, by species and by sector. Compared with the decreasing or flat emission trend during 1995-2000 (Hao et al., 2002; Streets et al., 2001), all species show an increasing trend during 2001-2006: 36\% increase for $\mathrm{SO}_{2}, 55 \%$ for $\mathrm{NO}_{\mathrm{x}}, 18 \%$ for $\mathrm{CO}, 29 \%$ for VOC, $13 \%$ for $\mathrm{PM}_{10}$, and $14 \%$ for $\mathrm{PM}_{2.5}, \mathrm{BC}$, and $\mathrm{OC}$. These emission increases can be viewed in the context of $92 \%$ growth of GDP and $72 \%$ increase of total energy consumption in the same period. 
Table 5. Anthropogenic emissions in China in the year 2001 (units: Gg/year).*

\begin{tabular}{lrrrrr}
\hline Species & Power & Industry & Residential & Transportation & Total \\
\hline $\mathrm{SO}_{2}$ & $12270(1.22)$ & $7946(1.08)$ & $2599(1.03)$ & $75(0.18)$ & $22891(1.13)$ \\
$\mathrm{NO}_{\mathrm{x}}$ & $5390(1.22)$ & $3405(1.22)$ & $997(1.42)$ & $3604(1.37)$ & $13397(1.27)$ \\
$\mathrm{CO}$ & $1861(\mathrm{n} / \mathrm{a})$ & $53526(2.97)$ & $48254(1.10)$ & $37930(1.00)$ & $141571(1.42)$ \\
$\mathrm{NMVOC}$ & $547(6.02)$ & $4982(1.34)$ & $5996(1.07)$ & $6547(1.23)$ & $18072(1.23)$ \\
$\mathrm{PM}_{10}$ & $1873(\mathrm{n} / \mathrm{a})$ & $9647(\mathrm{n} / \mathrm{a})$ & $4258(\mathrm{n} / \mathrm{a})$ & $292(\mathrm{n} / \mathrm{a})$ & $16070(\mathrm{n} / \mathrm{a})$ \\
$\mathrm{PM}_{2.5}$ & $1152(\mathrm{n} / \mathrm{a})$ & $6398(\mathrm{n} / \mathrm{a})$ & $3853(\mathrm{n} / \mathrm{a})$ & $284(\mathrm{n} / \mathrm{a})$ & $11687(\mathrm{n} / \mathrm{a})$ \\
$\mathrm{BC}$ & $38(5.59)$ & $545(6.13)$ & $868(1.11)$ & $143(2.40)$ & $1595(1.70)$ \\
$\mathrm{OC}$ & $8(1.52)$ & $496(17.95)$ & $2254(0.88)$ & $70(1.35)$ & $2827(1.06)$ \\
\hline
\end{tabular}

* Numbers in parentheses represent the emission ratio between this inventory for the year 2001 (R01) and the TRACE-P inventory for the year 2000 (T00).

Table 6. Anthropogenic emissions in China in the year 2006 (units: Gg/year). ${ }^{*}$

\begin{tabular}{lrrrrr}
\hline Species & Power & Industry & Residential & Transportation & Total \\
\hline $\mathrm{SO}_{2}$ & $18333(1.49)$ & $9725(1.22)$ & $2838(1.09)$ & $123(1.64)$ & $31020(1.36)$ \\
$\mathrm{NO}_{\mathrm{x}}$ & $9197(1.71)$ & $5371(1.58)$ & $1166(1.17)$ & $5096(1.41)$ & $20830(1.55)$ \\
$\mathrm{CO}$ & $2362(1.27)$ & $74936(1.40)$ & $55883(1.16)$ & $33709(0.89)$ & $166889(1.18)$ \\
$\mathrm{NMVOC}$ & $961(1.76)$ & $8056(1.62)$ & $7601(1.27)$ & $6630(1.01)$ & $23247(1.29)$ \\
$\mathrm{PM}_{10}$ & $2476(1.32)$ & $10436(1.08)$ & $4884(1.15)$ & $427(1.46)$ & $18223(1.13)$ \\
$\mathrm{PM}_{2.5}$ & $1474(1.28)$ & $6932(1.08)$ & $4461(1.16)$ & $398(1.40)$ & $13266(1.14)$ \\
$\mathrm{BC}$ & $36(0.94)$ & $575(1.06)$ & $1002(1.15)$ & $198(1.38)$ & $1811(1.14)$ \\
$\mathrm{OC}$ & $6(0.72)$ & $505(1.02)$ & $2606(1.16)$ & $101(1.45)$ & $3217(1.14)$ \\
\hline
\end{tabular}

\footnotetext{
* Numbers in parentheses represent the emission ratio between the year 2006 (I06) and the year 2001 (R01).
}

It is quite clear that the dramatic emission increases in China after 2001 were driven by the economic boom and growing infrastructure investments. Figure 5 shows how China's power plants grew during 2001-2006 compared with the previous five years. Many energy-consuming activities doubled in just a few years in China, resulting in a significant increase in relevant emissions. For example, total thermal based electricity generation increased from 1.17 trillion $\mathrm{kWh}$ in 2001 to 2.37 trillion $\mathrm{kWh}$ in 2006 , and total vehicle numbers increased from 18 million to 37 million during the same period.

On the other hand, China has made substantial efforts on technology improvement and emission control during this period. These measures have offset the emission growth significantly. We note several developments that have had important impacts on emissions in the following areas:

a) New technologies with improved energy intensity and/or lower emissions. These technologies include: replacement of small power generation boilers by large ones that have better combustion efficiencies; use of power generation boilers with LNB technologies to reduce $\mathrm{NO}_{\mathrm{x}}$ emissions; replacement of indigenous processes by modern processes for coke production, resulting in a significant reduction of emissions; transition from shaft kilns to new-dry kilns in the cement industry, which reduces $\mathrm{CO}$ emissions (but increases $\mathrm{NO}_{\mathrm{x}}$ emissions);

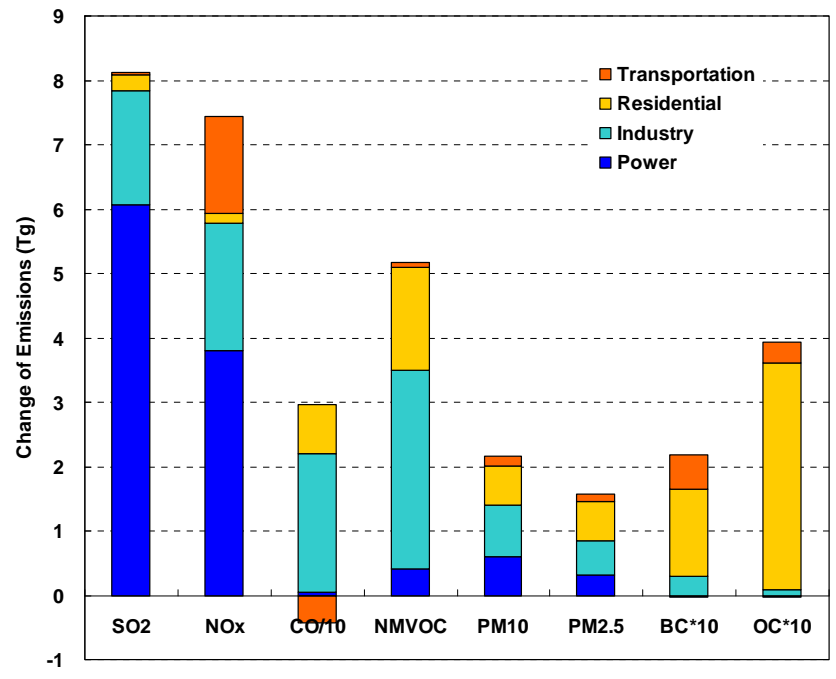

Fig. 4. Change of China's emissions between 2006 and 2001 by sector (units: Tg). 
(a)

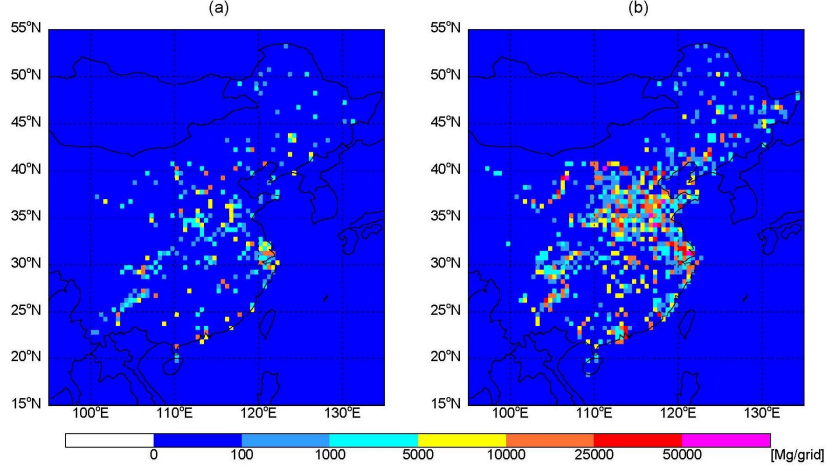

Fig. 5. $\mathrm{NO}_{\mathrm{x}}$ emission increase from China's power plants. Left panel: $\mathrm{NO}_{\mathrm{x}}$ emission change from China's power plants between 2001 and 1996. Right panel: $\mathrm{NO}_{\mathrm{x}}$ emission change from China's power plants between 2006 and 2001 (units: Mg per grid).

and advanced technologies to capture by-pass gas during iron and steel production, to avoid the $\mathrm{CO}$ releases from by-pass gas.

b) FGD installation on coal-fired power plants. As discussed in Sect. 2.3, FGD has been widely installed in power plants in recent years under new requirements of central and local government. By the end of 2006, 30\% of coal-fired power plants were equipped with $\mathrm{FGD}$, which is estimated to eliminate about $6 \mathrm{Tg}$ of $\mathrm{SO}_{2}$ emissions in that year. FGD penetration in power plants further increased to $50 \%$ at the end of 2007 , leading to a $4.7 \%$ reduction of national $\mathrm{SO}_{2}$ emissions in 2007, which is the first decrease in national $\mathrm{SO}_{2}$ emissions since the year 2002 (MEP, 2008).

c) Strengthened PM emission standards for cement plants and coal-fired power plants. Cement plants and coal-fired power plants contributed $37 \%$ and $10 \%$ of national $\mathrm{PM}_{2.5}$ emissions, respectively in 2001. In 2003 and 2004, China implemented new emission standards for these two sectors, which strengthened the limits for TSP emissions from 150 $600 \mathrm{mg} / \mathrm{Nm}^{3}$ to $50-100 \mathrm{mg} / \mathrm{Nm}^{3}$ for all cement plants, and from $200-600 \mathrm{mg} / \mathrm{Nm}^{3}$ to $50 \mathrm{mg} / \mathrm{Nm}^{3}$ for new coal-fired power plants (SEPA, 2003, 2004; CRAES, 2003). To meet these standards, high-efficiency PM removal equipment was widely installed, and some small, dirty factories were closed. As a result, $\mathrm{PM}_{2.5}$ emissions from cement plants and coalfired power plants decreased by $7 \%$ and increased by $23 \%$ during 2001-2006, respectively, in contrast to the doubled activity rates in each sector.

d) Emission standards for new vehicles. Table 4 lists the emission standards for new vehicles in China in recent years, and Fig. 3b shows the decreasing trend of emission factors when new vehicles join the fleet and replace old ones. CO emissions from the transportation sector decreased by $11 \%$ during 2001-2006 during a period when the total number of vehicles doubled, providing an excellent illustration of effective control measures. NMVOC emissions in 2006 were al- most the same as in 2001, while $\mathrm{NO}_{\mathrm{x}}$ emissions increased by $41 \%$, but still showing a much lower growth than the growth in the vehicle population.

Table 7 presents China's emissions by province for the year 2006. Emissions vary considerably from province to province, with the highest emissions mainly located in the eastern and central regions of China. Hebei, Henan, Jiangsu, Shandong, and Sichuan Provinces are the five largest contributors for most species. Shandong is the largest contributor for $\mathrm{SO}_{2}, \mathrm{NO}_{\mathrm{x}}, \mathrm{NMVOC}, \mathrm{PM}_{10}$, and $\mathrm{PM}_{2.5}$ and the second largest contributor for $\mathrm{CO}$ and $\mathrm{OC}$. Emissions from western provinces, e.g., Qinghai and Xizang, were much less than from eastern ones. The regional differences of emissions are mainly caused by differences of economic development, industry structure, and population.

\subsection{Total Asian emissions}

We estimate total Asian anthropogenic emissions in the year 2006 as follows: $47.0 \mathrm{Tg} \mathrm{SO}_{2}, 36.8 \mathrm{Tg} \mathrm{NO}_{\mathrm{x}}, 298.1 \mathrm{Tg} \mathrm{CO}$, 54.6 Tg NMVOC, 28.9 Tg PM $10,22.0 \mathrm{Tg} \mathrm{PM}_{2.5}, 2.91 \mathrm{Tg} \mathrm{BC}$, and $6.54 \mathrm{Tg}$ OC. These values are not directly comparable with the TRACE-P inventory due to the fundamental changes in methodologies discussed previously. However, most impacts of methodology improvement can be removed by replacing the China part of the TRACE-P inventory with the R01 inventory of this work. Then we can compare the revised TRACE-P Asian emissions with our new estimates, to explore the actual emission changes during the intervening years. Asian emissions continue the significant increasing trends that have been reported in the last two decades (van Aardenne et al., 1999; Streets et al., 2001; Ohara et al., 2007). From the beginning of the 21 st century, Asian anthropogenic emissions increased by $33 \%$ for $\mathrm{SO}_{2}, 44 \%$ for $\mathrm{NO}_{\mathrm{x}}$, $18 \%$ for CO, $25 \%$ for NMVOC, and $9 \%$ for BC in just 5 years. The most significant growth was found for $\mathrm{NO}_{\mathrm{x}}$ emissions, which is driven by both industrial and vehicular emissions. In contrast, $\mathrm{BC}$ emissions, which are dominated by the residential sector, show a relatively small increase. OC emissions decreased by $9 \%$, but this cannot be viewed as a real emission decrease, because in this 2006 inventory we used lower estimates of emissions from Reddy and Venkataraman $(2002 a, b)$ than the TRACE-P estimates. Reddy and Venkataraman (2002a, b) estimated that the OC emissions in India were $1.0 \mathrm{Tg}$ in 1999, much lower than TRACE-P estimates of $2.2 \mathrm{Tg}$ in 2000 . The main reason for this difference is that Reddy and Venkataraman (2002b) used lower OC emission factors for biofuel combustion.

Table 8 summarizes the emissions of each species in each country in 2006, and Fig. 6 shows the shares of emissions among different sub-regions of Asia. China and India are the two most important individual contributors to Asian emissions. China's contributions to total Asian emissions are: $66 \%$ for $\mathrm{SO}_{2}, 57 \%$ for $\mathrm{NO}_{\mathrm{x}}, 56 \%$ for $\mathrm{CO}, 43 \%$ for $\mathrm{NMVOC}$, $63 \%$ for $\mathrm{PM}_{10}, 60 \%$ for $\mathrm{PM}_{2.5}, 62 \%$ for $\mathrm{BC}$, and $49 \%$ for 
Table 7. Anthropogenic emissions in China by province in 2006 (units: Gg/year).

\begin{tabular}{lllllllll}
\hline Province & $\mathrm{SO}_{2}$ & $\mathrm{NO}_{\mathrm{x}}$ & $\mathrm{CO}$ & $\mathrm{VOC}$ & $\mathrm{PM}_{10}$ & $\mathrm{PM}_{2.5}$ & $\mathrm{BC}$ & $\mathrm{OC}$ \\
\hline Anhui & 693 & 715 & 7986 & 958 & 757 & 574 & 84 & 173 \\
Beijing & 248 & 327 & 2591 & 497 & 123 & 90 & 19 & 19 \\
Chongqing & 1211 & 326 & 2928 & 343 & 340 & 257 & 34 & 75 \\
Fujian & 460 & 547 & 3895 & 701 & 435 & 337 & 44 & 127 \\
Gansu & 338 & 323 & 2688 & 303 & 296 & 222 & 35 & 55 \\
Guangdong & 1175 & 1493 & 8693 & 1780 & 942 & 680 & 55 & 120 \\
Guangxi & 880 & 435 & 4258 & 640 & 468 & 348 & 40 & 94 \\
Guizhou & 1952 & 485 & 4409 & 481 & 571 & 435 & 90 & 162 \\
Hainan & 76 & 83 & 724 & 117 & 67 & 53 & 7 & 18 \\
Hebei & 2281 & 1308 & 15505 & 1521 & 1371 & 981 & 137 & 200 \\
Heilongjiang & 242 & 839 & 4967 & 771 & 579 & 440 & 72 & 144 \\
Henan & 1591 & 1197 & 10957 & 1289 & 1193 & 834 & 133 & 197 \\
Hong Kong & 118 & 148 & 127 & 109 & 27 & 18 & 1 & 1 \\
Hubei & 2200 & 930 & 7482 & 875 & 772 & 559 & 73 & 137 \\
Hunan & 915 & 563 & 5124 & 641 & 576 & 424 & 54 & 105 \\
Jiangsu & 1697 & 1486 & 11326 & 1814 & 1200 & 881 & 87 & 186 \\
Jiangxi & 533 & 390 & 3963 & 463 & 586 & 400 & 39 & 76 \\
Jilin & 357 & 473 & 3794 & 523 & 395 & 293 & 45 & 82 \\
Liaoning & 1027 & 955 & 8105 & 989 & 710 & 512 & 64 & 111 \\
Nei Mongol & 1171 & 860 & 5253 & 575 & 574 & 420 & 71 & 113 \\
Ningxia & 380 & 175 & 961 & 131 & 134 & 98 & 11 & 18 \\
Qinghai & 18 & 46 & 616 & 74 & 70 & 54 & 8 & 11 \\
Shaanxi & 907 & 352 & 3528 & 491 & 474 & 328 & 49 & 81 \\
Shandong & 3102 & 1759 & 14970 & 2093 & 1702 & 1212 & 132 & 213 \\
Shanghai & 618 & 631 & 1958 & 594 & 138 & 91 & 10 & 8 \\
Shanxi & 1804 & 934 & 5787 & 627 & 969 & 669 & 139 & 158 \\
Sichuan & 2555 & 873 & 10945 & 1312 & 1068 & 845 & 133 & 318 \\
Tianjin & 336 & 365 & 1860 & 381 & 161 & 109 & 15 & 18 \\
Xinjiang & 210 & 356 & 2775 & 391 & 257 & 194 & 37 & 55 \\
Xizang & 0 & 5 & 94 & 14 & 9 & 6 & 1 & 1 \\
Yunnan & 489 & 344 & 3765 & 515 & 454 & 343 & 56 & 97 \\
Zhejiang & 1434 & 1106 & 4857 & 1233 & 806 & 556 & 36 & 45 \\
China Total & 31020 & 20830 & 166889 & 23247 & 18223 & 13266 & 1811 & 3217 \\
\hline & & & & & & & & \\
\hline
\end{tabular}

OC. India follows China as the second largest contributor with the following shares: $12 \%$ for $\mathrm{SO}_{2}, 13 \%$ for $\mathrm{NO}_{\mathrm{x}}$, $20 \%$ for CO, $20 \%$ for NMVOC, $14 \%$ for $\mathrm{PM}_{10}, 14 \%$ for $\mathrm{PM}_{2.5}, 12 \%$ for BC, and $14 \%$ for OC. Other countries contribute much smaller individual shares. China's contribution to Asian emissions has increased since the year 2000, reflecting faster economic development and industrialization than other Asian developing countries. South Asia and Southeast Asia contribute significantly to emissions of CO, NMVOC, and $\mathrm{OC}$, due to the large amount of residential biofuel use.

Figure 7 compares the sectoral contributions of Asian emissions in 2000 and 2006. The sectoral distribution of emissions is similar between the two years, with some small but meaningful changes. The contribution from power plants to $\mathrm{SO}_{2}$ and $\mathrm{NO}_{\mathrm{x}}$ emissions has increased, driven by the industrialization progress and spread of electrification in the past years. Although the vehicle stocks in Asia increased

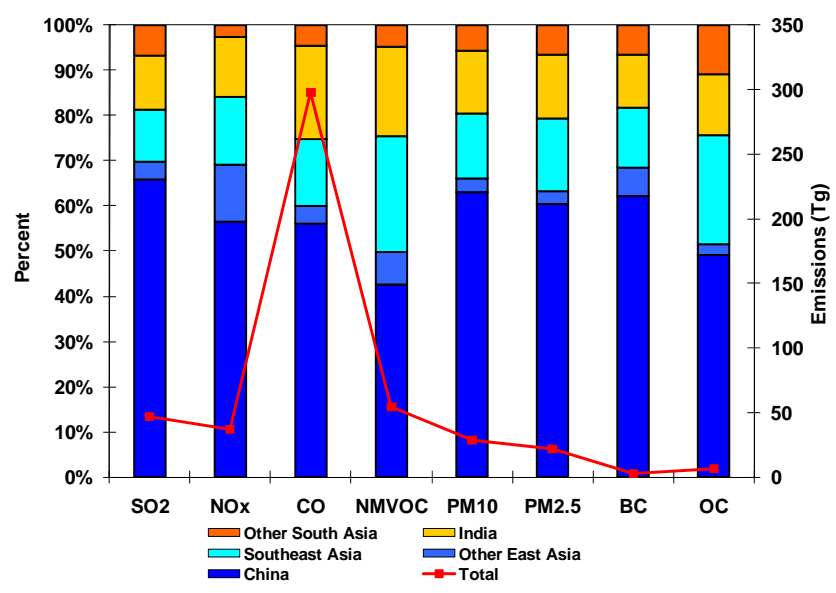

Fig. 6. Species emissions by Asian region and absolute values of emissions. 
Table 8. Summary of national emissions in Asia in 2006 (units: Gg/year).

\begin{tabular}{|c|c|c|c|c|c|c|c|c|}
\hline Country & $\mathrm{SO}_{2}$ & $\mathrm{NO}_{\mathrm{x}}$ & $\mathrm{CO}$ & NMVOC & $\mathrm{PM}_{10}$ & $\mathrm{PM}_{2.5}$ & $\mathrm{BC}$ & $\mathrm{OC}$ \\
\hline China & 31020 & 20830 & 166889 & 23247 & 18223 & 13266 & 1811 & 3217 \\
\hline Japan $^{\mathrm{a}}$ & 871 & 2404 & 5314 & 2033 & 195 & 141 & 51 & 21 \\
\hline Korea, Rep of & $408^{\mathrm{b}}$ & $1307^{\mathrm{b}}$ & $789^{b}$ & $796^{\mathrm{b}}$ & $67^{\mathrm{b}}$ & 54 & 17 & 11 \\
\hline Korea, DPR & 233 & 270 & 3583 & 212 & 301 & 245 & 21 & 95 \\
\hline Mongolia & 84 & 38 & 351 & 23 & 27 & 22 & 2 & 9 \\
\hline Taiwan, China ${ }^{\mathrm{c}}$ & 189 & 642 & 1672 & 864 & 337 & 175 & 91 & 9 \\
\hline Brunei & 7 & 23 & 15 & 46 & 4 & 3 & 0 & 0 \\
\hline Cambodia & 34 & 27 & 570 & 113 & 68 & 61 & 7 & 32 \\
\hline Indonesia & 1451 & 1583 & 17742 & 6617 & 1838 & 1610 & 170 & 803 \\
\hline Laos & 8 & 18 & 195 & 61 & 22 & 20 & 2 & 11 \\
\hline Malaysia & 1137 & 1664 & 4286 & 1267 & 471 & 322 & 14 & 40 \\
\hline Myanmar & 51 & 85 & 2568 & 641 & 271 & 244 & 29 & 130 \\
\hline Philippines & 943 & 310 & 1998 & 1157 & 231 & 199 & 23 & 96 \\
\hline Singapore & 163 & 193 & 149 & 101 & 32 & 22 & 2 & 1 \\
\hline Thailand & 1299 & 1278 & 7189 & 2638 & 475 & 388 & 49 & 141 \\
\hline Vietnam & 385 & 330 & 9843 & 1441 & 737 & 657 & 90 & 326 \\
\hline Bangladesh & 148 & 182 & 3218 & 550 & 438 & 390 & 43 & 205 \\
\hline Bhutan & 5 & 5 & 97 & 21 & 12 & 11 & 1 & 6 \\
\hline India & $5596^{\mathrm{d}}$ & 4861 & 61106 & 10767 & 4002 & 3111 & $344^{\mathrm{d}}$ & $888^{\mathrm{d}}$ \\
\hline Nepal & 31 & 27 & 1659 & 251 & 205 & 186 & 21 & 103 \\
\hline Pakistan & 2882 & 681 & 7378 & 1405 & 873 & 752 & 115 & 349 \\
\hline Sri Lanka & 98 & 72 & 1501 & 371 & 100 & 88 & 11 & 44 \\
\hline Asia 2006 Total & 47045 & 36829 & 298112 & 54620 & 28930 & 21967 & 2914 & 6537 \\
\hline Asia 2000 Total $^{\mathrm{e}}$ & 35450 & 25540 & 252891 & 43538 & $\mathrm{n} / \mathrm{a}$ & $\mathrm{n} / \mathrm{a}$ & 2679 & 7209 \\
\hline $2006 / 2000$ & 1.33 & 1.44 & 1.18 & 1.25 & $\mathrm{n} / \mathrm{a}$ & $\mathrm{n} / \mathrm{a}$ & 1.09 & 0.91 \\
\hline
\end{tabular}

${ }^{a}$ From Kannari et al. (2007); ${ }^{b}$ from NIER (2008); ${ }^{c}$ from Fu et al. (2009); ${ }^{d}$ based on Reddy and Venkataraman (2002a, b) and scaled to the year 2006; ${ }^{\mathrm{e}}$ here Asia 2000 emissions consist of R01 inventory for China and TRACE-P inventory for other Asian countries, to better represent the real-world Asia emissions around the year 2000.

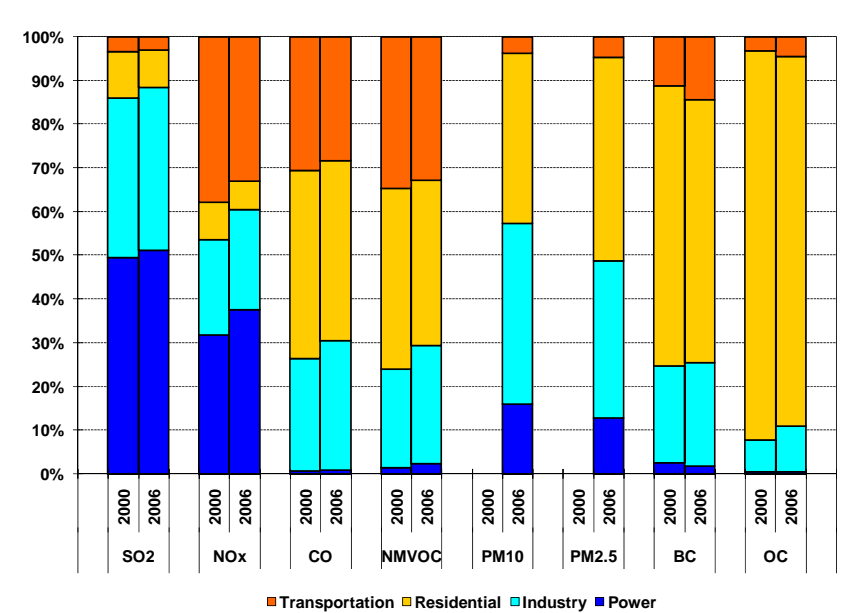

Fig. 7. Share of emissions by sector in Asia in 2000 and 2006. dramatically during the past few years, the relative contributions from the transportation sector decreased for $\mathrm{NO}_{\mathrm{x}}$, $\mathrm{CO}$, and NMVOC, indicating the effectiveness of control measures on gasoline vehicles. However, the increasing contribution of transportation emissions to carbonaceous aerosols indicates the expanding diesel vehicle fleet and slow progress on control measures for diesel particles.

\subsection{Seasonality of emissions}

In the TRACE-P inventory, Streets et al. (2003a) developed seasonal variations of residential energy consumption, assuming a dependence of stove operation on regional monthly mean temperatures. However, no seasonal variation was considered for the power generation and industrial sectors in the TRACE-P inventory. In this work, we follow the same methodology to generate monthly emissions for the residential sector for the whole of Asia, but also develop monthly emissions for power generation and industry for China according to the monthly activity data on power generation, cement production, and industrial GDP at the provincial level (Beijing Huatong Market Information Co. Ltd, 2006; China Statistical Information and Consultancy Center, 2006). 
Table 9. Monthly anthropogenic emissions in China in 2006 (units: Gg/month).

\begin{tabular}{lllllllllllll}
\hline Species & Jan & Feb & Mar & Apr & May & Jun & Jul & Aug & Sep & Oct & Nov & Dec \\
\hline $\mathrm{SO}_{2}$ & 2853 & 2416 & 2628 & 2368 & 2389 & 2430 & 2472 & 2485 & 2460 & 2503 & 2794 & 3220 \\
$\mathrm{NO}_{\mathrm{x}}$ & 1839 & 1666 & 1770 & 1627 & 1631 & 1654 & 1667 & 1675 & 1667 & 1697 & 1866 & 2071 \\
$\mathrm{CO}$ & 18051 & 15123 & 14677 & 12194 & 12131 & 12382 & 11714 & 11911 & 12302 & 12806 & 15041 & 18552 \\
$\mathrm{NMVOC}$ & 2528 & 2154 & 2034 & 1707 & 1702 & 1727 & 1663 & 1684 & 1720 & 1778 & 2037 & 2513 \\
$\mathrm{PM}_{10}$ & 1808 & 1516 & 1575 & 1356 & 1361 & 1401 & 1320 & 1346 & 1395 & 1445 & 1673 & 2026 \\
$\mathrm{PM}_{2.5}$ & 1416 & 1166 & 1163 & 963 & 962 & 986 & 934 & 951 & 982 & 1023 & 1211 & 1507 \\
$\mathrm{BC}$ & 240 & 189 & 168 & 120 & 117 & 118 & 114 & 116 & 118 & 126 & 164 & 221 \\
$\mathrm{OC}$ & 511 & 385 & 310 & 193 & 185 & 183 & 182 & 183 & 182 & 200 & 283 & 419 \\
\hline
\end{tabular}

(a) $\mathrm{SO} 2$
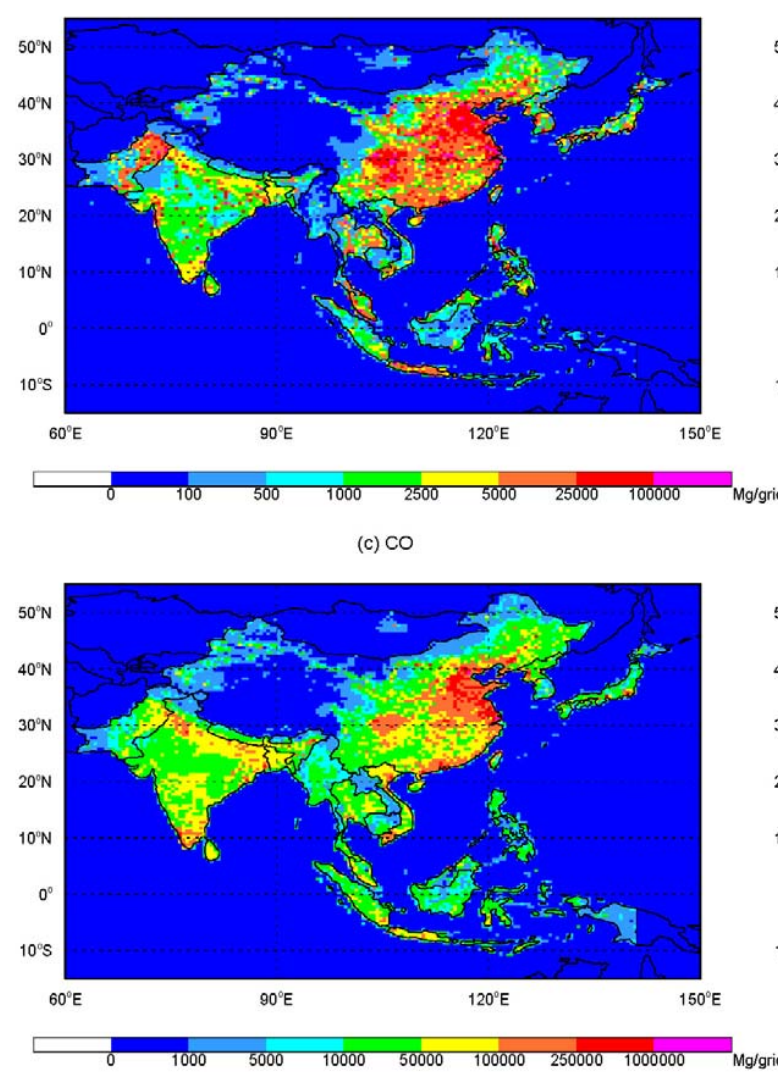

(b) NOx

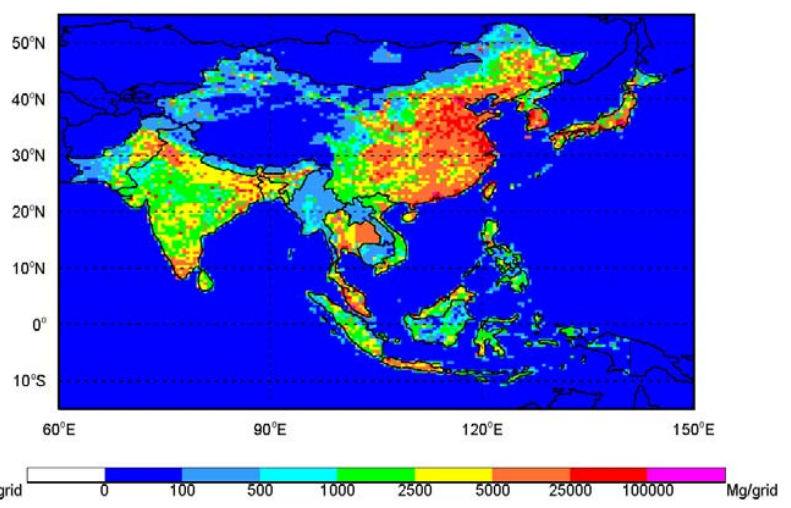

(d) NMVOC

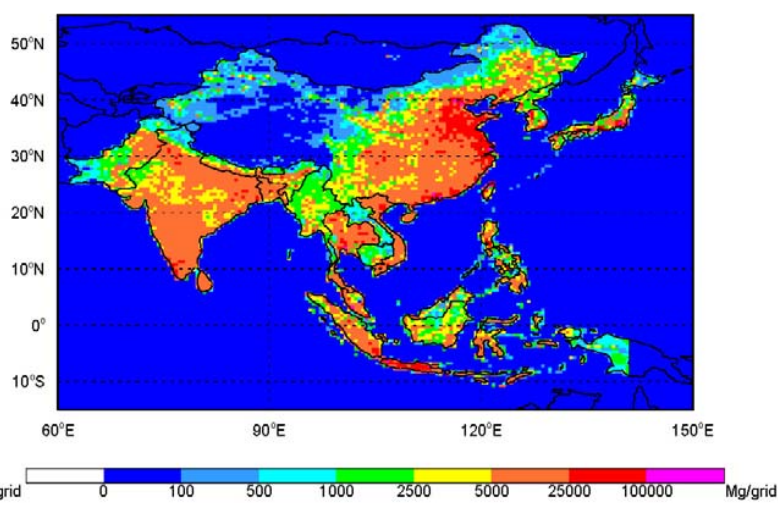

Fig. 8. Emission distributions at $30 \mathrm{~min} \times 30 \mathrm{~min}$ resolution of gaseous species (units: $\mathrm{Mg} / \mathrm{year}$ per grid).

Table 9 presents monthly emissions in China in 2006 by species. Strong seasonal variations are observed for CO, BC, and $\mathrm{OC}$, where the residential sector contributes the largest portion of emissions. The ratios of monthly $\mathrm{CO}, \mathrm{BC}$, and OC emissions between maxima and minima are 1.6, 2.1, and 2.8 , respectively. In contrast, $\mathrm{SO}_{2}$ and $\mathrm{NO}_{\mathrm{x}}$ emissions have weaker seasonal variations, with ratios of 1.4 and 1.3 between maxima and minima, because they mainly come from industrial and transportation emissions that have less of a seasonal cycle. We also find that $\mathrm{SO}_{2}$ and $\mathrm{NO}_{\mathrm{x}}$ emissions in
February are lower than in neighboring months, because of reduced industrial activity during the Chinese Spring Festival holiday.

\subsection{Gridded emissions}

Figures 8 and 9 show the spatial distribution of gaseous pollutants and aerosol emissions in Asia in 2006 at a resolution of $30 \mathrm{~min} \times 30 \mathrm{~min}$. Emissions are distributed using various spatial proxies at $1 \mathrm{~km} \times 1 \mathrm{~km}$ resolution (Streets et al., 2003a; Woo et al., 2003). For Japan, Korea, Taiwan, 
(a) PM10

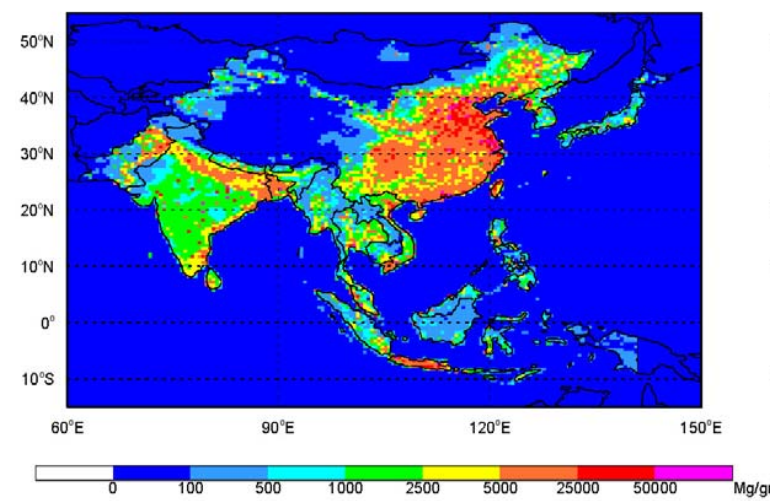

(c) $\mathrm{BC}$

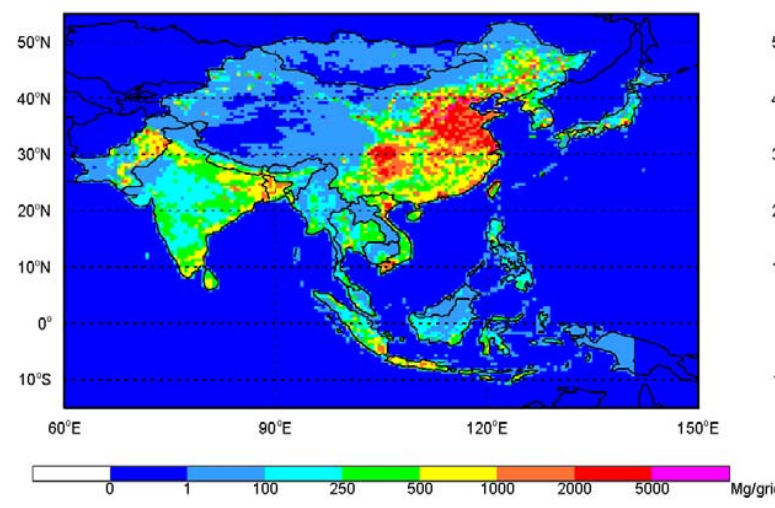

(b) PM2.5

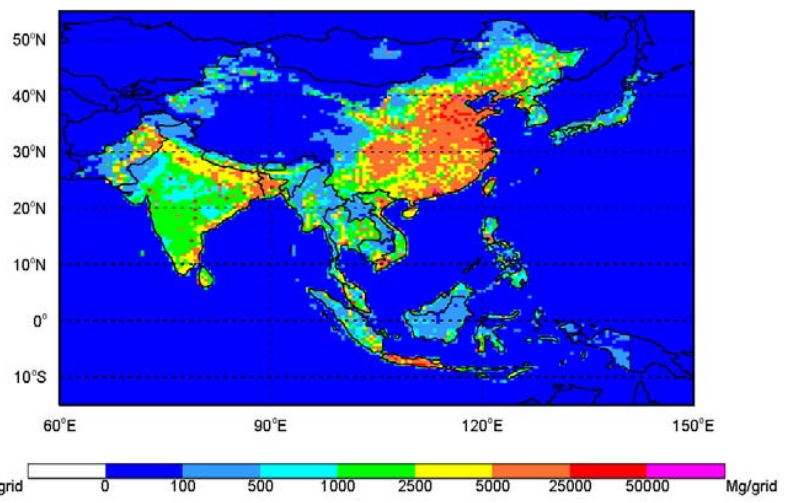

(d) $\mathrm{OC}$

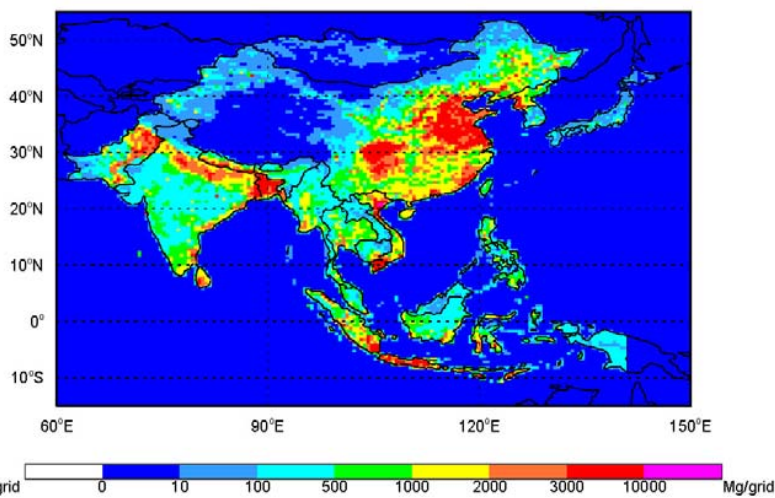

Fig. 9. Emission distributions at $30 \mathrm{~min} \times 30 \mathrm{~min}$ resolution of aerosol species (units: $\mathrm{Mg}$ /year per grid).

and India, where the emissions were obtained from national inventories, we keep the spatial distribution characteristics of the original inventories and simply re-grid them to $30 \mathrm{~min} \times 30 \mathrm{~min}$ resolution. All power generation units with capacity larger than $300 \mathrm{MW}$ ( $\sim 400$ units) in China are identified as large point sources, while other plants are treated as area sources.

\subsection{Data access}

All regional and gridded emission data sets can be downloaded from our web site (http://mic.greenresource.cn/ intex-b2006). Users can examine emissions by country and by sector from the summary tables. Gridded data include the emissions of all species by sector (power, industry, residential, and transportation) at $30 \mathrm{~min} \times 30 \mathrm{~min}$ resolution. At the time this paper was submitted, NMVOC emissions speciated according to the SAPRC-99 mechanism are available by sector (power, industry, residential biofuel, residential fossil fuel, residential non-combustion, and transportation) for download at $30 \mathrm{~min} \times 30 \mathrm{~min}$ resolution, but we will add speciated VOC emissions for other mechanisms later. These emission data are also downloadable from the website at the University of Iowa (http://www.cgrer.uiowa.edu/ EMISSION_DATA_new/index_16.html).

\section{Discussion}

\subsection{Magnitude of China's emissions in inventories and top-down constraints}

Ohara et al. (2007) conducted a comprehensive comparison of different emission inventories for Asia, China, and India during 1995-2000 and discussed the reasons for the differences. In this section, we will not repeat that comparison, but focus instead on a comparison of the magnitude of China's emissions in inventories and from top-down constraints for years after 2000 (Table 10), in order to highlight the implications for emission inventory development.

a) Sulfur Dioxide. $\mathrm{SO}_{2}$ is one of the few pollutants for which China's government reports national emissions annually. Our estimate for the year 2006 is $20 \%$ higher than SEPA reported; however, the two estimates generally agree well at the sector level, considering that SEPA's estimate does not include emissions from rural industries and residential biofuels. The increasing trends of the two estimates are also similar: we estimate a $35 \%$ increase of $\mathrm{SO}_{2}$ emissions in 20012006, while SEPA presented a $33 \%$ increase during the same period. Our estimates for the year 2001 are close to the value of the TRACE-P inventory, but significantly lower than the 
Table 10. Estimates of China's and East Asian annual emissions after the year 2000. ${ }^{\mathrm{a}}$

\begin{tabular}{|c|c|c|c|c|c|c|c|c|c|c|}
\hline Pollutant and Study & Method $^{\mathrm{b}}$ & Sources $^{c}$ & Region & 2000 & 2001 & 2002 & 2003 & 2004 & 2005 & 2006 \\
\hline \multicolumn{11}{|l|}{$\mathrm{SO}_{2}$} \\
\hline Streets et al. (2003a) & EI & $\mathrm{FF}+\mathrm{BF}$ & China & 20.3 & & & & & & \\
\hline Olivier et al. (2005) & EI & $\mathrm{FF}+\mathrm{BF}$ & China & 34.2 & & & & & & \\
\hline Ohara et al. (2007) & EI & $\mathrm{FF}+\mathrm{BF}$ & China & 27.6 & 29.3 & 31.9 & 36.6 & & & \\
\hline SEPA & EI & $\mathrm{FF}^{\mathrm{d}}$ & China & 20.0 & 19.5 & 19.3 & 21.6 & 22.5 & 25.5 & 25.9 \\
\hline This work & EI & $\mathrm{FF}+\mathrm{BF}$ & China & & 22.9 & & & & & 31.0 \\
\hline \multicolumn{11}{|l|}{$\mathrm{NO}_{\mathrm{x}}$} \\
\hline Streets et al. (2003a) & EI & $\mathrm{FF}+\mathrm{BF}$ & China & 10.5 & & & & & & \\
\hline Olivier et al. (2005) & EI & $\mathrm{FF}+\mathrm{BF}$ & China & 13.7 & & & & & & \\
\hline Ohara et al. (2007) & EI & $\mathrm{FF}+\mathrm{BF}$ & China & 11.2 & 11.8 & 12.7 & 14.5 & & & \\
\hline $\begin{array}{l}\text { Zhang et al. (2007b) } \\
\text { and this work }\end{array}$ & EI & $\mathrm{FF}+\mathrm{BF}$ & China & 12.6 & 13.2 & 14.4 & 16.2 & 18.6 & 19.8 & 20.8 \\
\hline Wang et al. (2004) & IM & $\mathrm{FF}+\mathrm{BF}+\mathrm{BB}+\mathrm{SL}$ & China & & 16.5 & & & & & \\
\hline Jaegle et al. (2005) & IM & $\mathrm{FF}+\mathrm{BF}$ & China & 14.5 & & & & & & \\
\hline Martin et al. (2006) & IM & $\mathrm{FF}+\mathrm{BF}+\mathrm{BB}+\mathrm{SL}$ & East Asia & & & & & 32.2 & & \\
\hline \multicolumn{11}{|l|}{$\mathrm{CO}$} \\
\hline Streets et al. (2003a) & EI & $\mathrm{FF}+\mathrm{BF}$ & China & 100 & & & & & & \\
\hline Olivier et al. (2005) & EI & $\mathrm{FF}+\mathrm{BF}$ & China & 87 & & & & & & \\
\hline $\begin{array}{l}\text { Streets et al. (2006) } \\
\text { and this work }\end{array}$ & EI & $\mathrm{FF}+\mathrm{BF}$ & China & & 142 & & & & & 167 \\
\hline Ohara et al. (2007) & EI & $\mathrm{FF}+\mathrm{BF}$ & China & 137 & 141 & 146 & 158 & & & \\
\hline Palmer et al. (2003a) & IM & $\mathrm{FF}+\mathrm{BF}$ & China & & 168 & & & & & \\
\hline Arellano et al. (2004) & IM & $\mathrm{FF}+\mathrm{BF}+\mathrm{BB}$ & East Asia & $196-214$ & & & & & & \\
\hline Heald et al. (2004) & IM & $\mathrm{FF}+\mathrm{BF}+\mathrm{BB}$ & East Asia & & 192 & & & & & \\
\hline Wang et al. (2004) & IM & $\mathrm{FF}+\mathrm{BF}+\mathrm{BB}$ & China & & 166 & & & & & \\
\hline Petron et al. (2004) & IM & $\mathrm{FF}+\mathrm{BF}+\mathrm{BB}$ & East Asia & 186 & & & & & & \\
\hline Yumimoto and Uno (2006) & IM & $\mathrm{FF}+\mathrm{BF}+\mathrm{BB}$ & China & & 147 & & & & & \\
\hline Tanimoto et al. (2008) & IM & $\mathrm{FF}+\mathrm{BF}+\mathrm{BB}$ & China & & & & & & 170 & \\
\hline Kopacz et al. (2009) & IM & $\mathrm{FF}+\mathrm{BF}+\mathrm{BB}$ & China & & 141.5 & & & & & \\
\hline Carmichael et al. (2003b) & FM & $\mathrm{FF}+\mathrm{BF}+\mathrm{BB}$ & China & & $163-210$ & & & & & \\
\hline Heald et al. (2003) & FM & $\mathrm{FF}+\mathrm{BF}+\mathrm{BB}$ & China & & 181 & & & & & \\
\hline Allen et al. (2004) & FM & $\mathrm{FF}+\mathrm{BF}$ & China & & 145 & & & & & \\
\hline Tan et al. (2004) & FM & $\mathrm{FF}+\mathrm{BF}+\mathrm{BB}$ & China & & 174 & & & & & \\
\hline \multicolumn{11}{|l|}{ VOC } \\
\hline Streets et al. (2003a) & EI & $\mathrm{FF}+\mathrm{BF}$ & China & 14.7 & & & & & & \\
\hline Olivier et al. (2005) & EI & $\mathrm{FF}+\mathrm{BF}$ & China & 11.5 & & & & & & \\
\hline Wei et al. (2008) & EI & $\mathrm{FF}+\mathrm{BF}$ & China & & & & & & 20.1 & \\
\hline Bo et al. (2008) & EI & $\mathrm{FF}+\mathrm{BF}+\mathrm{BB}$ & China & 11.0 & & & & & 16.5 & \\
\hline This work & EI & $\mathrm{FF}+\mathrm{BF}$ & China & & 18.1 & & & & & 23.2 \\
\hline Fu et al. (2007) & IM & $\mathrm{FF}+\mathrm{BF}+\mathrm{BB}$ & China & $21.7^{\mathrm{e}}$ & & & & & & \\
\hline \multicolumn{11}{|l|}{$\mathrm{BC} / \mathrm{OC}$} \\
\hline Streets et al. (2003a) & EI & $\mathrm{FF}+\mathrm{BF}$ & China & $0.94 / 2.66$ & & & & & & \\
\hline Bond et al. (2004) & EI & $\mathrm{FF}+\mathrm{BF}$ & China & $1.36 / 2.11$ & & & & & & \\
\hline Cao et al. (2006) & EI & $\mathrm{FF}+\mathrm{BF}$ & China & $1.40 / 3.81$ & & & & & & \\
\hline Ohara et al. (2007) & EI & $\mathrm{FF}+\mathrm{BF}$ & China & $1.09 / 2.56$ & $1.10 / 2.58$ & $1.11 / 2.60$ & $1.14 / 2.62$ & & & \\
\hline This work & EI & $\mathrm{FF}+\mathrm{BF}$ & China & & $1.60 / 2.83$ & & & & & $1.81 / 3.22$ \\
\hline
\end{tabular}

${ }^{a}$ Units are $\mathrm{Tg}$ /year. Units for $\mathrm{NO}_{\mathrm{x}}$ are $\mathrm{Tg}-\mathrm{NO}_{2} /$ year. ${ }^{\mathrm{b}} \mathrm{EI}=$ emission inventory; $\mathrm{IM}=$ inverse modeling; $\mathrm{FM}=$ forward modeling. ${ }^{\mathrm{c}} \mathrm{FF}=$ fossil fuel; $\mathrm{BF}=$ biofuel combustion; $\mathrm{BB}=$ open biomass burning; and $\mathrm{SL}=$ soil emissions. ${ }^{\mathrm{d}}$ Only includes fossil-fuel emissions from power plants and industry. ${ }^{\mathrm{e}} \mathrm{Fu}$ et al. (2007), required a $25 \%$ increase in reactive VOC emissions from the TRACE-P inventory (including BB emissions) to agree with inverse modeling.

values estimated by REAS (Ohara et al., 2007) and EDGAR (Olivier et al., 2005).

It appears that the magnitude of China's $\mathrm{SO}_{2}$ emissions in the TRACE-P inventory is reasonable on the basis of CTM model simulations and comparison with in situ measurements (Carmichael et al., 2003b; Russo et al., 2003; Tan et al., 2004). The accuracy of our $\mathrm{SO}_{2}$ estimate for the year 2006 is of more concern, because we have no guarantees that the recently installed FGD equipment is run continuously, as we assume. This could impact China's $\mathrm{SO}_{2}$ emission trend significantly. Recent developments on satellite-based $\mathrm{SO}_{2}$ column observations show good potential for constraining 
surface emissions (Richter et al., 2006; Krotkov et al., 2008). Further trend analysis of satellite $\mathrm{SO}_{2}$ columns over China may be able to provide valuable information for verifying $\mathrm{SO}_{2}$ emissions.

b) Nitrogen Oxides. $\mathrm{NO}_{\mathrm{x}}$ emission estimates for China are all quite close (see Table 10). Analysis from modeling and measurements during the TRACE-P campaign also indicated that the estimates of China's $\mathrm{NO}_{\mathrm{x}}$ emissions in the TRACE-P inventory are reasonably accurate (Carmichael et al., 2003b). However, several inverse modeling analyses constrained by satellite-based data concluded that China's $\mathrm{NO}_{\mathrm{x}}$ emission inventory was significantly underestimated (Martin et al., 2003, 2006; Jaeglé et al., 2005; Wang et al., 2007). In the meantime, forward modeling studies also under-predicted $\mathrm{NO}_{2}$ columns compared to satellite retrievals by a factor of two over East China, which is usually attributed to underestimation of $\mathrm{NO}_{\mathrm{x}}$ emissions (Ma et al., 2006; Uno et al., 2007). China's $\mathrm{NO}_{\mathrm{x}}$ emissions are mainly contributed by power plants and vehicles, and there is no clear evidence to suggest such a remarkable underestimation of emissions from those two sectors from the perspective of inventory development. One plausible reason is that current estimates of soil $\mathrm{NO}_{\mathrm{x}}$ emissions are too low (Wang et al., 2007), and further investigations are required to reconcile $\mathrm{NO}_{\mathrm{x}}$ emission estimates over China.

c) Carbon Monoxide. Analysis of $\mathrm{CO}$ observations using chemical transport models in inverse and forward modes suggested that previous China's $\mathrm{CO}$ inventories were underestimated by about $50 \%$ at the time of the TRACE-P mission (Carmichael et al., 2003b; Heald et al., 2003, 2004; Palmer et al., 2003a; Allen et al., 2004; Arellano et al., 2004; Petron et al., 2004; Tan et al., 2004; Wang et al., 2004), as shown in Table 10. Motivated by those top-down constraints, we reexamined the source characteristics and concluded that emissions from cement kilns, brick kilns, and the iron and steel industry were underestimated (Streets et al., 2006). Bottom-up and modeled emission estimates are now in good agreement (Yumimoto and Uno, 2006; Tanimoto et al., 2008; Kopacz et al., 2009), which represents a major success story for the TRACE-P mission. This was the first study in which bottom-up and top-down approaches for quantifying China's emissions were truly integrated. Inadequacies in the bottom-up approach were identified by top-down studies, and the findings from the top-down studies were able to be used to improve our understanding of emissions and guide improvement of the bottom-up inventory.

d) Nonmethane Volatile Organic Compounds. Wei et al. (2008) and Bo et al. (2008) recently estimated China's NMVOC emissions for the year 2005. Our estimates for the year 2006 are 15\% higher than Wei et al. (2008). Considering the emission growth from 2005 to 2006, these two estimates may actually be in reasonable agreement. Bo et al. (2008) presented lower NMVOC emissions than both Wei et al. (2008) and this work, which seems to be due to their low estimates for stationary combustion emissions.
Satellite observations of formaldehyde columns offer topdown constraints on reactive NMVOC emissions (Palmer et al., 2003b, 2006; Millet et al., 2006). Fu et al. (2007) found that wintertime GOME observations can diagnose anthropogenic reactive NMVOC emissions from China, leading to an estimate $25 \%$ higher than the TRACE-P inventory, which is in good agreement with our new estimates for the year 2001 (23\% higher than the TRACE-P inventory). Modeling evaluations of the TRACE-P inventory using field measurements from the TRACE-P campaign concluded that the inventory performed well for the light alkanes and ethyne, but estimates for other speciated NMVOCs are highly uncertain (Carmichael et al., 2003b). Speciated NMVOC emissions are highly dependent on the source profiles used. In this work, we applied both local source profiles and international profiles when developing speciated VOC emissions, to investigate the impact of different source profiles on emissions. This work is documented in Zhang et al. (2009).

e) Black Carbon. The range of 2000/2001 estimates for China's anthropogenic BC emissions varies from $0.94 \mathrm{Tg}$ to $1.60 \mathrm{Tg}$ (see Table 10). This is not surprising because of the high uncertainties in emission estimates. Analysis of forward and inverse model calculations using TRACE-P and ACE-Asia measurement data concluded that the TRACE-P estimates of BC are qualitatively correct (Carmichael et al., 2003b; Uno et al., 2003b; Clarke et al., 2004; Hakami et al., 2005), but Tan et al. (2004) suggested a 60-90\% increase of TRACE-P BC emissions was necessary to bring the modelpredicted $\mathrm{BC}$ concentrations into agreement with in situ measurements. However, Carmichael et al. (2003b) pointed out a systematic problem in under-predicting BC levels at low altitudes in the Yellow Sea; Clarke et al. (2004) found that $\mathrm{BC}$ emissions from combustion sources north of $25^{\circ} \mathrm{N}$ were underestimated by a factor of $\sim 3$, and Hakami et al. (2005) concluded that anthropogenic BC emissions over Southeastern China were overestimated while those in Northeast China were underestimated. These findings indicated that the regional distributions of the current $\mathrm{BC}$ inventory are questionable, although emission estimates of the TRACE-P inventory may be correct at the national level. One possible reason for this situation is discussed below (Sect. 4.3.2).

\subsection{Constraining the trajectory of China's emission trends}

Recent developments in satellite observations allow for the development of long-term emission trends, which is very helpful for constraining emission inventories. Satelliteobserved tropospheric $\mathrm{NO}_{2}$ columns have been widely used for evaluating the recent dramatic increase in $\mathrm{NO}_{\mathrm{x}}$ emissions over China (e.g., Richter et al., 2005; van de A et al., 2006, 2008; Stavrakou et al., 2008). We have developed a 10-year trend of $\mathrm{NO}_{\mathrm{x}}$ emissions in China during 1995-2004 and compared it with the satellite observations (Zhang et al., 2007b). The growth rate from the emission inventory is lower 
than that from the satellite observations. We found quantitative agreement during summertime but a large discrepancy during winter time. Additional analysis is needed to find the reason of the discrepancy, but the consistency between the summertime trends suggests that the bias cannot be associated with systematic error of the basic inventory data. In this work, we estimate that $\mathrm{NO}_{\mathrm{x}}$ emissions in China increased by $55 \%$ during 2001-2006, at a $9.2 \%$ annual growth rate. This is comparable with the satellite-inferred trend of $\mathrm{NO}_{2}$ columns over China for recent years (Table 11).

Satellite-inferred trends also show good agreement with our inventory for other species. Tanimoto et al. (2008) obtained a 3.8\% annual growth rate of Chinese $\mathrm{CO}$ emissions during 2000-2005, by using MOPPIT satellite observations and inverse modeling methods. This is in good agreement with the 3.4\% annual growth rate during 2001-2006 from this work. van Donkelaar et al. (2008) analyzed aerosol data from MISR and MODIS for 2000-2006 with the GEOSChem model to estimate annual growth in Chinese sulfur emissions of $6.2 \%$ and $9.6 \%$, respectively, which is comparable with the $6.3 \%$ annual growth rate of Chinese $\mathrm{SO}_{2}$ emissions during 2001-2006 in this work.

\subsection{Main uncertainties in this inventory}

Compared with the TRACE-P inventory, we believe that emission estimates for China in this work are significantly improved as a result of our detailed technology approach and other methodological improvement. We also believe that the emission estimates for Japan, Korea, and Taiwan in this work are improved from the TRACE-P inventory, as they rely on thorough inventory compilation at the local level with local knowledge. For other Asian countries (mainly in Southeast Asia), the accuracy of the estimates is less than in other regions, as activity data were extrapolated from the year 2004 and few local emission factors were applied. So users should be cautioned if using this inventory for the Southeast Asia region specifically. The uncertainty of this inventory in Southeast Asia is at about the same level as the TRACE-P inventory, because the same methodology was used.

For the TRACE-P inventory, a detailed uncertainty analysis was performed for each species by combining emission measurement uncertainties with uncertainties in activity levels (Streets et al., 2003a). The overall uncertainty in TRACE-P emissions for all of Asia was calculated as follows, ranked in increasing order of uncertainty and measured as $95 \%$ confidence intervals: $\pm 16 \%\left(\mathrm{SO}_{2}\right), \pm 37 \%$ $\left(\mathrm{NO}_{\mathrm{x}}\right), \pm 130 \%$ (NMVOC), $\pm 185 \%$ (CO), $\pm 360 \%$ (BC), and $\pm 450 \%$ (OC). It is impossible for us to conduct such an analysis for the whole of Asia in this work, since we use several local emission inventories and their uncertainties are not known. However, we have repeated the TRACE-P uncertainty analysis for China, by taking into account the new emission factor data and the improved estimates of activity levels by sector, fuel, and technology type. The uncertainties for China's emissions in the year 2006 are estimated as follows: $\pm 12 \%\left(\mathrm{SO}_{2}\right), \pm 31 \%\left(\mathrm{NO}_{\mathrm{x}}\right), \pm 68 \%$ (NMVOC), $\pm 70 \%$ (CO), $\pm 132 \%\left(\mathrm{PM}_{10}\right), \pm 130 \%\left(\mathrm{PM}_{2.5}\right), \pm 208 \%$ (BC), and $\pm 258 \%$ (OC). Compared with the TRACE-P inventory, the uncertainties in $\mathrm{SO}_{2}$ and $\mathrm{NO}_{\mathrm{x}}$ emissions are similar, while other species show significant improvements in accuracy. These improvements are mainly gained from the technologybased methodology.

The uncertainties in emission estimates for China vary considerably across sectors and source types. Uncertainties in power-plant emissions are less than for other sectors, because the activity data are well known and local emission factors are available. This is confirmed by a recent unitbased power-plant emission inventory for China (Zhao et al., 2008): our estimates are in good agreement with the unitbased estimates. We also feel comfortable with the estimates for the cement industry and the iron and steel industry, because factory-level information was applied when building this inventory. The larger remaining uncertainties are now confined to small industries, residential combustion, and the transportation sector.

\subsubsection{Small industries}

Bond et al. (2004) concluded that coke production and brick production are important emitting sources for China, which were omitted in previous inventory studies. Cao et al. (2006) also identified rural industry in China as an important contributor of carbonaceous aerosol emissions. These small industries are thought to be highly polluting, because the low level of technology inhibits the use of efficient control devices. In this work, we estimate that industrial processes contributed $0.45 \mathrm{Tg} \mathrm{BC}$ and $0.50 \mathrm{Tg}$ OC in 2006, mostly from coke production and brick production, by using the same emission factors as in Bond et al. (2004). However, we are not confident about these numbers, because those emission factors are based on very few measurements. Emission factors for coke ovens were determined using assumptions about actual operation conditions that have $100 \%$ uncertainty (Bond et al., 2004, Sect. 5.2.3). There is no information available on measured emission factors of traditional brick production. Emission factors were interpolated between values for home-heating stoves and stoker-fired boilers with high uncertainty (Bond et al., 2004). Local measurements on those sources are required to remedy this situation and narrow the range of uncertainty.

\subsubsection{Residential coal combustion}

The residential sector has been identified as a major cause of uncertainty in estimates of $\mathrm{CO}, \mathrm{NMVOC}$, and carbonaceous aerosol emissions in Asia (Streets et al., 2003a), because of the lack of reliable statistics and local emission factor measurements. In this work, we follow the method used in the TRACE-P inventory for the residential sector, by applying a 
Table 11. Comparison of emission trends over China with top-down inferred methods.

\begin{tabular}{lllll}
\hline Species & Study & Method & Period & AGR $(\% / \mathrm{yr})^{\mathrm{a}}$ \\
\hline $\mathrm{SO}_{2}$ & van Donkelaar et al. (2008) & modeling and satellite & $2000-2006$ & $6.2,9.6^{\mathrm{b}}$ \\
& This work & inventory & $2001-2006$ & 6.3 \\
$\mathrm{NO}_{\mathrm{x}}$ & Richter et al. (2005) & satellite & $1996-2004$ & $8.7^{\mathrm{c}}$ \\
& Uno et al. (2007) & forward model & $2000-2002$ & $8-9$ \\
& Zhang et al. (2007b) & inventory & $1996-2004$ & 6.1 \\
& L. Zhang et al. (2008) & inverse modeling & $2000-2006$ & $12.2^{\mathrm{d}}$ \\
& Stavrakou et al. (2008) & satellite & $1997-2006$ & 7.3 \\
& This work & inventory & $2001-2006$ & 9.2 \\
$\mathrm{CO}$ & Tanimoto et al. (2008) & inverse modeling & $2001-2005$ & 3.8 \\
& This work & inventory & $2001-2006$ & 3.4 \\
\hline
\end{tabular}

${ }^{\text {a }}$ AGR = annual growth rate; ${ }^{\mathrm{b}} 6.2 \%$ AGR was inferred by MODIS satellite data, and $9.6 \%$ AGR was inferred by MISR; ${ }^{\mathrm{c}}$ Richter et al. (2005), presented trends for 1996-2002, here extended to 1996-2004 using the same dataset; ${ }^{\mathrm{d}}$ L. Zhang et al. (2008), argued that NO emissions in China increased by a factor of two during 2000-2006, constrained by GEOS-Chem Model and OMI observations, equal to a $12.2 \%$ AGR.

uniform emission factor for a given fuel for the whole sector. However, large variations of $\mathrm{BC}$ emission factors have been observed in residential coal combustion in recent measurements (Chen et al., 2005, 2006; Y. Zhang et al., 2008; Zhi et al., 2008), depending on coal type (bituminous or anthracite) and combustion type (raw coal or briquette). In this case, the average $\mathrm{BC}$ emission factor in residential combustion is dominated by the share of bituminous coal use and the share of raw coal use, because $\mathrm{BC}$ emissions from bituminous raw coal combustion are 30-500 times higher than others (Table 12). However, we don't know the real-world fraction of coal briquette use in China. The China Energy Statistical Yearbook only reports a small portion of residential coal use $(<10 \%)$ as coal briquettes, but actually coal briquettes are widely used in the residential sector. This results in difficulty in determining $\mathrm{BC}$ emission factors accurately. Figure 10 illustrates the dependence of BC emission factors on bituminous coal use and coal briquette use in China's residential coal combustion. We were able to identify BC emission factors for a few provinces such as Beijing, Fujian, and Shaanxi, but we do not know the situations in other provinces. This may result in significant errors in the regional distribution of $\mathrm{BC}$ emissions in China when applying a uniform emission factor for the whole of China. Remedying this problem will require a reassessment of China's official statistics for the residential sector.

\subsubsection{Vehicle emissions}

Recent estimates of China's vehicle emissions are surprisingly close (see Table 13), but this does not mean that the accuracy of the estimates is high. Even for developed countries, estimating vehicle emissions is still difficult. For example, Parrish (2005) argued that CO emissions from onroad vehicles in the US were overestimated by about a factor of two in USEPA's National Emissions Inventory. In China,
Table 12. BC emission factors for residential coal combustion.

\begin{tabular}{lll}
\hline & Bituminous coal & Anthracite coal \\
\hline Raw coal & $3.81^{\mathrm{a}} ; 2.75^{\mathrm{c}} ; 3.32^{\mathrm{d}}$ & $0.007^{\mathrm{a}} ; 0.028^{\mathrm{c}} ; 0.004^{\mathrm{d}}$ \\
Coal briquette & $0.082^{\mathrm{a}} ; 0.28^{\mathrm{b}} ; 0.095^{\mathrm{c}}$ & $0.004^{\mathrm{a}, \mathrm{b}}$ \\
\hline
\end{tabular}

a Zhi et al. (2008); ${ }^{b}$ Chen et al. (2005); ${ }^{c}$ Y. Zhang et al. (2008); ${ }^{d}$ Chen et al. (2006).

the quality of the vehicle emission inventory is downgraded by a couple of issues. First, transportation-related activity data are not well reported through the national or provincial statistical systems. Vehicle population data are usually available at provincial level only with simple classifications; transportation energy consumption is not properly reported in statistics; and systemic surveys of vehicle travel mileage are also absent. We have to use modeling methods to obtain some of the necessary activity data (He et al., 2005). On the other hand, there is no transportation emission model specifically designed for the China situation available for national emission inventory development. Emission models from developed countries have usually been applied in the past, using base emission factors from their own databases with assumptions and adjustments to match China's fleet structure (Streets et al., 2003a; Cai and Xie, 2007).

Recent efforts to develop high-resolution vehicle emission inventories for China are encouraging (Liu et al., 2007; Huo et al., 2009; Wang et al., 2009). Bottom-up methods were used in these studies, by collecting data on vehicle fleet composition, daily travel mileage, and driving patterns at city level, which can reduce estimation uncertainties significantly. Extending these activities to more cities would be very beneficial for national emission inventory development. Vehicle tests are also ongoing, to begin the development of emission factors specific to China. Continued 


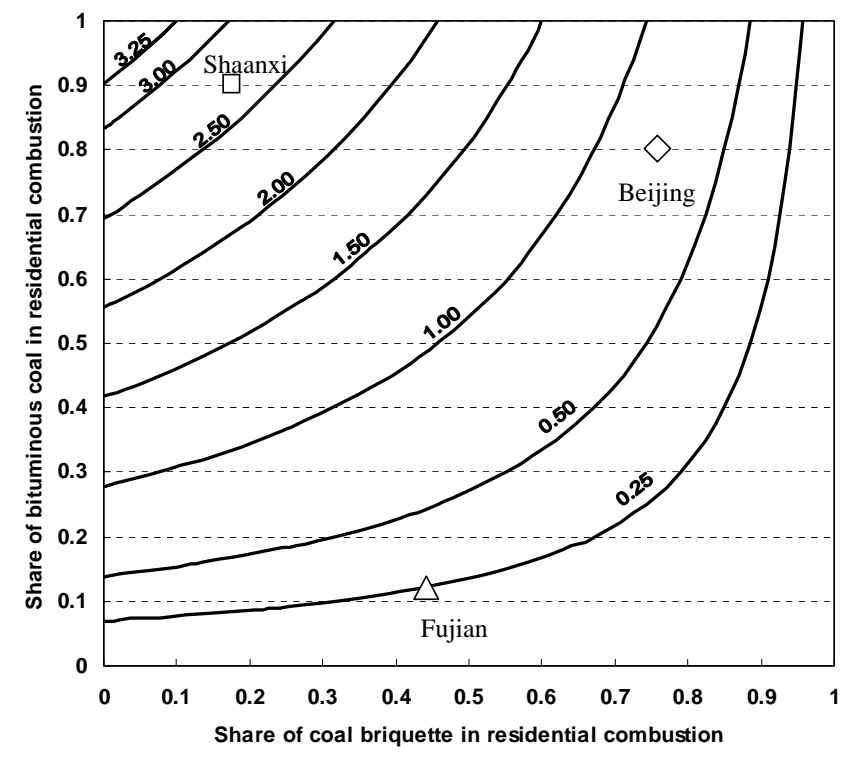

Fig. 10. Dependence of BC emission factors on bituminous coal use and coal briquette use in China's residential coal combustion. Contour lines represent the average BC emission factor (unit: $\mathrm{g} / \mathrm{kg}$ coal) in residential coal combustion. Diamond, square, and triangle dots represent the average BC emission factors in Beijing, Shaanxi, and Fujian, respectively.

updates and improvements in this field are required to gain a better understanding of emissions in China.

\subsection{Applications and evaluations of the inventory}

This inventory has been used in the modeling community during and after the INTEX-B mission. Initial results from the INTEX-B experiments are encouraging. By using this inventory and the GEOS-Chem model, van Donkelaar et al. (2008) and L. Zhang et al. (2008) examined the characteristics of Asian outflow and found that the model provides a good simulation of the $\mathrm{SO}_{\mathrm{x}}, \mathrm{SO}_{4}^{2-}$, ozone, $\mathrm{NO}_{\mathrm{x}}$, and PAN mean vertical profiles observed from INTEX-B aircraft. By comparing with the trend in satellite retrievals, they also found that this inventory well represented the $\mathrm{SO}_{2}$ and $\mathrm{NO}_{\mathrm{x}}$ emission increases in Asia between 2000 and 2006.

The $\mathrm{NO}_{\mathrm{x}}$ budget over East Asia has been investigated by integrating atmospheric models, satellite observations, and this inventory. Good agreement was found. Han et al. (2009) suggested that our estimates over North China, coupled with another Korean inventory, appear to provide a better estimation of the real world situation compared to the TRACE-P inventory. In two most recent inversion modeling studies using OMI and GOME2 satellite observations, the a posteriori estimates suggest that the $\mathrm{NO}_{\mathrm{x}}$ budget was close to (Lin et al., 2009) or slightly lower than (Zhao and Wang, 2009) the bottom-up estimates.
Table 13. China's vehicle emissions from recent inventory estimates (units: $\mathrm{Tg} /$ year).

\begin{tabular}{lcccc}
\hline & Year & $\mathrm{NO}_{\mathrm{x}}$ & $\mathrm{CO}$ & $\mathrm{VOC}$ \\
\hline Cai and Xie (2007) & 2005 & 4.5 & 36.2 & 5.9 \\
Bo et al. (2008) & 2005 & - & - & 5.5 \\
Wei et al. (2008) & 2005 & - & - & 5.6 \\
This work & 2006 & 5.1 & 33.7 & 6.6 \\
\hline
\end{tabular}

Several regional modeling studies have used this inventory and compared their model predictions against surface observations in China. Both consistencies and inconsistencies between model and observation were both found in those studies. Zhao et al. (2009) simulated ozone pollution over East China in 2004 by using a regional chemical transport model (REAM) and this inventory. The model errors for ozone simulation are within the recommend ranges of the USEPA, but the model significantly underestimates some ozone peaks at Mt. Tai. Chen et al. (2009) used a nested GEOS-Chem model and this inventory to investigate regional $\mathrm{CO}$ pollution over China. They found that the model predicted surface $\mathrm{CO}$ concentrations well at a suburban site near Beijing but underestimated CO concentrations significantly in the Beijing urban area during summer 2005. Finally, Matsui et al. (2009) found that CMAQ model calculations using this inventory cannot agree with all of the observations made in downtown and rural Beijing sites in summer 2006. Systematically large $\mathrm{SO}_{2} / \mathrm{CO}$ and $\mathrm{BC} / \mathrm{CO}$ ratios as compared with observations were found, indicating there are some inconsistencies in the emission data. Although emission estimates for the whole of China are thought to be more accurate than previous studies, there can still be large uncertainties remaining in individual locations. This is because emissions are estimated at the provincial level, while emission patterns may vary within a province due to local differences in economic and industrial structures. The next step of our work will be to better present the spatial pattern of the inventory at local level, by using more region-specific activity data/emission factors, and high-resolution GIS databases.

Acknowledgements. The work at Tsinghua University was supported by China's National Basic Research Program (2005CB422201) and China's National High Technology Research and Development Program (2006AA06A305). The work at Argonne National Laboratory was supported by NASA's INTEX program. We are grateful for the ongoing support of J. Crawford, D. Jacob, and H. Singh. K. B. He would like to thank the National Natural Science Foundation of China (20625722) for financial support. J. S. Fu would like to thank F.-L. Yeh for his help on Taiwan emissions. Argonne National Laboratory is operated by UChicago Argonne, LLC, under Contract No. DE-AC02-06CH11357 with the US Department of Energy.

Edited by: H. Singh 


\section{References}

Akimoto, H., Ohara, T., Kurokawa, J., and Horii, N.: Verification of energy consumption in China during 1996-2003 by using satellite observational data, Atmos. Environ., 40, 7663-7667, 2006.

Allen, D., Pickering, K., and Fox-Rabinovitz, K.: Evaluation of pollutant outflow and $\mathrm{CO}$ sources during TRACE-P using modelcalculated, aircraft-based, and Measurements of Pollution in the Troposphere (MOPITT)-derived CO concentrations, J. Geophys. Res., 109, D15S03, doi:10.1029/2003JD004250, 2004.

Arellano, A. F., Kasibhatla, P. S., Giglio, L., van der Werf, G. R., and Randerson, J. T.: Top-down estimates of global CO sources using MOPITT measurements, Geophys. Res. Lett., 31, L01104, doi:10.1029/2003GL018609, 2004.

AISIC (Association of Iron and Steel Industry in China): China Iron and Steel Statistics 2002, Beijing, 2002 (in Chinese).

AISIC (Association of Iron and Steel Industry in China): China Iron and Steel Statistics 2006, Beijing, 2006 (in Chinese).

Beijing Huatong Market Information Co. Ltd: China Latest Economic Indicators, Beijing, 2006 (in Chinese).

Bo, Y., Cai, H., and Xie, S. D.: Spatial and temporal variation of historical anthropogenic NMVOCs emission inventories in China, Atmos. Chem. Phys., 8, 7297-7316, 2008,

http://www.atmos-chem-phys.net/8/7297/2008/.

Bond, T. C., Streets, D. G., Fernandes, S. D., Nelson, S. M., Yarber, K. F., Woo, J.-H., and Klimont, Z.: A technologybased global inventory of black and organic carbon emissions from combustion, J. Geophys. Res., 109, D14203, doi:10.1029/2003JD003697, 2004.

Cai, H. and Xie, S.: Estimation of vehicular emission inventories in China from 1980 to 2005, Atmos. Environ., 41, 8963-8979, 2007.

Cao, G., Zhang, X., and Zheng, F.: Inventory of black carbon and organic carbon emissions from China, Atmos. Environ., 40, 6516-6527, 2006.

Carmichael, G. R., Tang, Y., Kurata, G., Uno, I., Streets, D., Woo, J. H., Huang, H., Yienger, J., Lefer, B., Shetter, R., Blake, D., Atlas, E., Fried, A., Apel, E., Eisele, F., Cantrell, C., Avery, M., Barrick, J., Sachse, G., Brune, W., Sandholm, S., Kondo, Y., Singh, H., Talbot, R., Bandy, A., Thorton, D., Clarke, A., and Heikes, B.: Regional-scale chemical transport modeling in support of the analysis of observations obtained during the TRACE-P experiment, J. Geophys. Res., 108, 8823, doi:10.1029/2002JD003117, 2003a.

Carmichael, G. R., Tang, Y., Kurata, G., Uno, I., Streets, D. G., Thongboonchoo, N., Woo, J.-H., Guttikunda, S., White, A., Wang, T., Blake, D. R., Atlas, E., Fried, A., Potter, B., Avery, M. A., Sachse, G. W., Sandholm, S. T., Kondo, Y., Talbot, R. W., Bandy, A., Thorton, D., and Clarke, A. D.: Evaluating regional emissions estimates using the TRACE-P observations, J. Geophys. Res., 108, 8810, doi:10.1029/2002JD003116, 2003 b.

Chen, D., Wang, Y., McElroy, M. B., He, K., Yantosca, R. M., and Le Sager, P.: Regional CO pollution and export in China simulated by the high-resolution nested-grid GEOS-Chem model, Atmos. Chem. Phys., 9, 3825-3839, 2009,

http://www.atmos-chem-phys.net/9/3825/2009/.

Chen, Y., Sheng, G., Bi, X., Feng, Y., Bai, B., and Fu, J.: Emission factors for carbonaceous particles and polycyclic aromatic hydrocarbons from residential coal combustion in China, Environ. Sci. Technol., 39, 1861-1867, 2005.
Chen, Y., Zhi, G., Feng, Y., Fu, J., Feng, J., Sheng, G., and Simoneit, B. R. T.: Measurements of emission factors for primary carbonaceous particles from residential rawcoal combustion in China, Geophys. Res. Lett., 33, L20815, doi:10.1029/2006GL026966, 2006.

China Statistical Information and Consultancy Center: Monthly Bulletin of Statistics - China, Beijing, 2006 (in Chinese).

Clarke, A. D., Shinozuka, Y., Kapustin, V. N., Howell, S., Huebert, B., Doherty, S., Anderson, T., Covert, D., Anderson, J., Hua, X., Moore II, K. G., McNaughton, C., Carmichael, G., and Weber, R.: Size distributions and mixtures of dust and black carbon aerosol in Asian outflow: Physiochemistry and optical properties, J. Geophys. Res., 109, D15S09, doi:10.1029/2003JD004378, 2004.

CRAES (Chinese Research Academy of Environmental Sciences): Description on developing emission standard of air pollutants for cement industry, internal report, 2003 (in Chinese).

Duncan, B. N., Martin, R. V., Staudt, A. C., Yevich, R., and Logan, J. A.: Interannual and seasonal variability of biomass burning emissions constrained by satellite observations, J. Geophys. Res., 108, 4100, doi:10.1029/2002JD002378, 2003.

Fu, J. S., Yeh, F. L., Jang, C. J., Chen, R. J. C., and Chuang, M. T.: Air quality modelling: an investigation of the merits of CMAQ in the analysis of trans-boundary air pollution from continents to small islands, Int. J. Environ. Technol. Manage., 10, 150-166, doi:10.1504/IJETM.2009.023520, 2009.

Fu, T.-M., Jacob, D. J., Palmer, P. I., Chance, K., Wang, Y. X., Barletta, B., Blake, D. R., Stanton, J. C., and Pilling, M. J.: Spacebased formaldehyde measurements as constraints on volatile organic compound emissions in East and South Asia, J. Geophys. Res., 112, D06312, doi:10.1029/2006JD007853, 2007.

Hakami, A., Henze, D. K., Seinfeld, J. H., Chai, T., Tang, Y., Carmichael, G. R., and Sandu, A.: Adjoint inverse modeling of black carbon during the Asian Pacific Regional Aerosol Characterization Experiment, J. Geophys. Res., 110, D14301, doi:10.1029/2004JD005671, 2005.

Han, K. M., Song, C. H., Ahn, H. J., Park, R. S., Woo, J. H., Lee, C. K., Richter, A., Burrows, J. P., Kim, J. Y., and Hong, J. H.: Investigation of $\mathrm{NO}_{\mathrm{X}}$ emissions and $\mathrm{NO}_{\mathrm{X}}$-related chemistry in East Asia using CMAQ-predicted and GOME-derived $\mathrm{NO}_{2}$ columns, Atmos. Chem. Phys., 9, 1017-1036, 2009, http://www.atmos-chem-phys.net/9/1017/2009/.

Hao, J., Tian, H., and Lu, Y.: Emission inventories of $\mathrm{NO}_{\mathrm{x}}$ from commercial energy consumption in China, 1995-1998, Environ. Sci. Technol., 36, 552-560, 2002.

He, K., Huo, H., Zhang, Q., He, D., An, F., Wang, M., and Walsh, M. P.: Oil consumption and $\mathrm{CO}_{2}$ emissions in China's road transport: current status, future trends, and policy implications, Energ. Policy, 33, 1499-1507, 2005.

Heald, C. L., Jacob, D. J., Fiore, A. M., Emmons, L. K., Gille, J. C., Deeter, M. N., Warner, J., Edwards, D. P., Crawford, J. H., Hamlin, A. J., Sachse, G. W., Browell, E. V., Avery, M. A., Vay, S. A., Westberg, D. J., Blake, D. R., Singh, H. B., Sandholm, S. T., Talbot, R. W., and Fuelberg, H. E.: Asian outflow and transPacific transport of carbon monoxide and ozone pollution: An integrated satellite, aircraft, and model perspective, J. Geophys. Res., 108, 4804, doi:10.1029/2003JD003507, 2003.

Heald, C. L., Jacob, D. J., Jones, D. B. A., Palmer, P. I., Logan, J. A., Streets, D. G., Sachse, G. W., Gille, J. C., Hoffman, R. N., 
and Nehrkorn, T.: Comparative inverse analysis of satellite (MOPITT) and aircraft (TRACE-P) observations to estimate Asian sources of carbon monoxide, J. Geophys. Res., 109, D23306, doi:10.1029/2004JD005185, 2004.

Horowitz, L. W., Walters, S. M., Mauzerall, D. L., Emmons, L. K., Rasch, P. J., Granier, C., Tie, X., Lamarque, J.-F., Schultz, M. G., and Brasseur, G. P.: A global simulation of tropospheric ozone and related tracers: Description and evaluation of MOZART, version 2, J. Geophys. Res., 108, 4784, doi:10.1029/2002JD002853, 2003.

Huo, H., Zhang, Q., He, K., Wang, Q., Yao, Z., and Streets, D. G.: High-resolution vehicular emission inventory using a link-based method: A case study of light-duty vehicles in Beijing, Environ. Sci. Technol., 43, 2394-2399, 2009.

IEA (International Energy Agency): Energy statistics of OECD countries and non-OECD countries, IEA, Paris, 2006.

Jacob, D. J., Crawford, J. H., Kleb, M. M., Connors, V. S., Bendura, R. J., Raper, J. L., Sachse, G. W., Gille, J. C., Emmons, L., and Heald, C. L.: The Transport and Chemical Evolution over the Pacific (TRACE-P) aircraft mission: design, execution, and first results, J. Geophys. Res., 108, 9000, doi:10.1029/2002JD003276, 2003.

Jaeglé, L., Steinberger, L., Martin, R. V., and Chance, K.: Global partitioning of $\mathrm{NO}_{\mathrm{x}}$ sources using satellite observations: Relative roles of fossil fuel combustion, biomass burning and soil emissions, Faraday Discuss., 130, 407-423, 2005.

Kannari, A., Tonooka, Y., Baba, T., and Murano, K.: Development of multiple-species $1 \mathrm{~km} \times 1 \mathrm{~km}$ resolution hourly basis emissions inventory for Japan, Atmos. Environ., 41, 3428-3439, 2007.

Klimont, Z., Cofala, J., Schopp, W., Amann, M., Streets, D. G., Ichikawa, Y., and Fujita, S.: Projections of $\mathrm{SO}_{2}, \mathrm{NO}_{\mathrm{x}}, \mathrm{NH}_{3}$ and VOC emissions in East Asia up to 2030, Water Air Soil Poll., 130, 193-198, 2001.

Klimont, Z., Streets, D. G., Gupta, S., Cofala, J., Fu, L., and Ichikawa, Y.: Anthropogenic emissions of non-methane volatile organic compounds in China, Atmos. Environ., 36, 1309-1322, 2002.

Kopacz, M., Jacob, D. J., Henze, D. K., Heald, C. L., Streets, D. G., and Zhang, Q.: Comparison of adjoint and analytical Bayesian inversion methods for constraining Asian sources of carbon monoxide using satellite (MOPITT) measurements of CO columns, J. Geophys. Res., 114, D04305, doi:10.1029/2007JD009264., 2009.

Krotkov, N. A., McClure, B., Dickerson, R. R., Carn, S. A., Li, C., Bhartia, P. K., Yang, K., Krueger, A. J., Li, Z., Levelt, P. F., Chen, $\mathrm{H}$., Wang, P., and $\mathrm{Lu}$, D.: Validation of $\mathrm{SO}_{2}$ retrievals from the Ozone Monitoring Instrument over NE China, J. Geophys. Res., 113, D16S40, doi:10.1029/2007JD008818, 2008.

Lin, J.-T., McElroy, M. B., and Boersma, K. F.: Constraint on anthropogenic $\mathrm{NO}_{\mathrm{x}}$ emissions in China from different sectors: A new methodology using multiple satellite retrievals, The 4th GEOS-Chem Scientific and User's Meeting, Cambridge, MA, USA, 7-10 April, 2009.

Liu, H., He, K., Wang, Q., Huo, H., Lents, J., Navis, N., Nikkila, N., Chen, C., Osses, M., and He, C.: Comparison of vehicle activity between Beijing and Shanghai, J. Air Waste Manage., 57, 11721177, 2007.

Liu, Y., Shao, M., Fu, L., Lu, S., Zeng, L., and Tang, D.: Source profiles of volatile organic compounds (VOCs) measured in China:
Part I, Atmos. Environ., 42, 6247-6260, 2008.

Ma, J., Richter, A., Burrows, J. P., Nüß, H., and van Aardenne, J. A.: Comparison of model-simulated tropospheric $\mathrm{NO}_{2}$ over China with GOME-satellite data, Atmos. Environ., 40, 593-604, 2006.

Martin, R. V., Jacob, D. J., Chance, K., Kurosu, T. P., Palmer, P. I., and Evans, M. J.: Global inventory of nitrogen oxide emissions constrained by space-based observations of $\mathrm{NO}_{2}$ columns, J. Geophys. Res., 108, 4537, doi:10.1029/2003JD003453, 2003.

Martin, R. V., Sioris, C. E., Chance, K., Ryerson, T. B., Bertram, T. H., Wooldridge, P. J., Cohen, R. C., Neuman, J. A., Swanson, A., and Flocke, F. M.: Evaluation of space-based constraints on global nitrogen oxide emissions with regional aircraft measurements over and downwind of eastern North America, J. Geophys. Res., 111, D15308, doi:10.1029/2005JD006680, 2006.

Matsui, H., Koike, M., Kondo, Y., Takegawa, N., Kita, K., Miyazaki, Y., Hu, M., Chang, S. Y., Blake, D. R., Fast, J. D., Zaveri, R. A., Streets, D. G., Zhang, Q., and Zhu, T.: Spatial and temporal variations of aerosols around Beijing in the summer 2006: 1. model evaluation and source apportionment, J. Geophys. Res., doi:10.1029/2008JD010906, in press, 2009.

MEP (Ministry of Environmental Protection of China): Report on the State of the Environment in China 2007, Beijing, 2008.

Millet, D. B., Jacob, D. J., Turquety, S., Hudman, R. C., Wu, S., Fried, A., Walega, J., Heikes, B. G., Blake, D. R., Singh, H. B., Anderson, B. E., and Clarke, A. D.: Formaldehyde distribution over North America: Implications for satellite retrievals of formaldehyde columns and isoprene emission, J. Geophys. Res., 111, D24S02, doi:10.1029/2005JD006853, 2006.

National Bureau of Statistics: China Statistical Yearbook 2002, China Stat. Press, Beijing, 2002a.

National Bureau of Statistics: China Industrial Economy Statistical Yearbook 1997-2001, China Stat. Press, Beijing, 2002b.

National Bureau of Statistics: China Energy Statistical Yearbook 2000-2002, China Stat. Press, Beijing, 2004.

National Bureau of Statistics: China Statistical Yearbook 2006, China Stat. Press, Beijing, 2006.

National Bureau of Statistics: China Energy Statistical Yearbook 2006, China Stat. Press, Beijing, 2007a.

National Bureau of Statistics: China Industrial Economy Statistical Yearbook 2006, China Stat. Press, Beijing, 2007b.

NIER (National Institute of Environmental Research of Korea): Annual Report for The 5th year's Joint Research on Long-range Transboundary Air Pollutants in Northeast Asia, Government Publication Registration Number: 11-1480083-000286-10, 277 pp., 2005.

NIER (National Institute of Environmental Research of Korea): 2006 Greenhouse Gas and Air Pollutants Emissions in Korea, 2008.

Ohara, T., Akimoto, H., Kurokawa, J., Horii, N., Yamaji, K., Yan, X., and Hayasaka, T.: An Asian emission inventory of anthropogenic emission sources for the period 1980-2020, Atmos. Chem. Phys., 7, 4419-4444, 2007,

http://www.atmos-chem-phys.net/7/4419/2007/.

Olivier, J. G. J., van Aardenne, J. A., Dentener, F., Pagliari, V., Ganzeveld, L. N., and Peters, J. A. H. W.: Recent trends in global greenhouse gas emissions: regional trends 1970-2000 and spatial distribution of key sources in 2000, Env. Sc., 2, 81-99, doi:10.1080/15693430500400345, 2005. 
Palmer, P. I., Jacob, D. J., Jones, D. B. A., Heald, C. L., Yantosca, R. M., Logan, J. A., Sachse, G. W., and Streets, D. G.: Inverting for emissions of carbon monoxide from Asia using aircraft observations over the western Pacific, J. Geophys. Res., 108, 8828, doi:10.1029/2003JD003397, 2003a.

Palmer, P. I., Jacob, D. J., Fiore, A. M., Martin, R. V., Chance, K., and Kurosu, T. P.: Mapping isoprene emissions over North America using formaldehyde column observations from space, J. Geophys. Res., 108, 4180, doi:10.1029/2002JD002153, 2003 b.

Palmer, P. I., Abbott, D. S., Fu, T.-M., Jacob, D. J., Chance, K., Kurosu, T. P., Guenther, A., Wiedinmyer, C., Stanton, J. C., Pilling, M. J., Pressley, S. N., Lamb, B., and Sumner, A. L.: Quantifying the seasonal and interannual variability of North American isoprene emissions using satellite observations of the formaldehyde column, J. Geophys. Res., 111, D12315, doi:10.1029/2005JD006689, 2006.

Parrish, D. D.: Critical evaluation of US on-road vehicle emission inventories, Atmos. Environ., 40, 2288-2300, 2005.

Petron, G., Granier, C., Khattatov, B., Yudin, V., Lamarque, J., Emmons, L., Gille, J., and Edwards, D. P.: Monthly CO surface sources inventory based on the 20002001 MOPITT satellite data, Geophys. Res. Lett., 31, L21107, doi:10.1029/2004GL020560, 2004.

Randerson, J. T., van der Werf, G. R., Giglio, L., Collatz, G. J., and Kasibhatla, P. S.: Global Fire Emissions Database, Version 2 (GFEDv2.1), Data set available on-line (http://daac.ornl.gov/) from Oak Ridge National Laboratory Distributed Active Archive Center, Oak Ridge, Tennessee, USA, doi:10.3334/ORNLDAAC/849, 2007.

Reddy, S. M. and Venkataraman, C.: Inventory of aerosol and sulphur dioxide emissions from India: Part I - fossil fuel combustion, Atmos. Environ., 36, 677-697, 2002a.

Reddy, S. M. and Venkataraman, C.: Inventory of aerosol and sulphur dioxide emissions from India: Part II - biomass combustion, Atmos. Environ., 36, 699-712, 2002b.

Richter, A., Burrows, J. P., Nüß, H., Granier, C., and Niemeier, U.: Increase in tropospheric nitrogen dioxide levels over China observed from space, Nature, 437, 129-132, 2005.

Richter, A., Wittrock, F., and Burrows, J. P.: $\mathrm{SO}_{2}$ measurements with SCIAMACHY, in Proceedings of the Atmospheric Science Conference, 8-12 May 2006, ESRIN, Frascati (CD-ROM), Eur. Space Agen., Spec. Publ. ESA SP-628, 2006.

RIVM: The IMAGE 2.2 Implementation of the SRES Scenarios: A Comprehensive Analysis of Emissions, Climate Change and Impacts in the 21st Century (RIVM CD-ROM publication 481508018), National Institute for Public Health and the Environment (RIVM), Bilthoven, The Netherlands, 2001.

Russo, R. S., Talbot, R. W., Dibb, J. E., Scheuer, E., Seid, G., Jordan, C. E., Fuelberg, H. E., Sachse, G. W., Avery, M. A., Vay, S. A., Blake, D. R., Blake, N. J., Atlas, E., Fried, A., Sandholm, S. T., Tan, D., Singh, H. B., Snow, J., and Heikes, B. G.: Chemical composition of Asian continental outflow over the western Pacific: Results from Transport and Chemical Evolution over the Pacific (TRACE-P), J. Geophys. Res., 108, 8804, doi:10.1029/2002JD003184, 2003.

SEPA (State Environmental Protection Administration of China): Emission standard of air pollutants for thermal power plants, GB 13223-2003, Beijing, 2003.

SEPA (State Environmental Protection Administration of China):
Emission standard of air pollutants from cement industry, GB 4915-2004, Beijing, 2004.

Singh, H. B., Brune, W. H., Crawford, J. H., Fuelberg, H., and Jacob, D. J.: The Intercontinental Chemical Transport Experiment - Phase B (INTEX-B): An update, NASA Earth Science Project Office, 2006.

Singh, H. B., Brune, W. H., Crawford, J. H., Flocke, F., and Jacob, D. J.: Chemistry and transport of pollution over the Gulf of Mexico and the Pacific: spring 2006 INTEX-B campaign overview and first results, Atmos. Chem. Phys., 9, 2301-2318, 2009, http://www.atmos-chem-phys.net/9/2301/2009/.

Stavrakou, T., Müller, J.-F., Boersma, K. F., De Smedt, I., and van der A, R. J.: Assessing the distribution and growth rates of $\mathrm{NO}_{\mathrm{x}}$ emission sources by inverting a 10 -year record of $\mathrm{NO}_{2}$ satellite columns, Geophys. Res. Lett., 35, L10801, doi:10.1029/2008GL033521, 2008.

Streets, D. G., Tsai, N. Y., Akimoto, H., and Oka, K.: Trends in emissions of acidifying species in Asia, 1985-1997, Water Air Soil Poll., 130, 187-192, 2001.

Streets, D. G., Bond, T. C., Carmichael, G. R., Fernandes, S. D., Fu, Q., He, D., Klimont, Z., Nelson, S. M., Tsai, N. Y., Wang, M. Q., Woo, J.-H., and Yarber, K. F.: An inventory of gaseous and primary aerosol emissions in Asia in the year 2000, J. Geophys. Res., 108, 8809, doi:10.1029/2002JD003093, 2003a.

Streets, D. G., Yarber, K. F., Woo, J.-H., and Carmichael, G. R.: Biomass burning in Asia: Annual and seasonal estimates and atmospheric emissions, Global Biogeochem. Cy., 17, 1099, doi:10.1029/2003GB002040, 2003b.

Streets, D. G., Zhang, Q., Wang, L., He, K., Hao, J., Wu, Y., Tang, Y., and Carmichael, G. R.: Revisiting China's CO emissions after TRACE-P: Synthesis of inventories, atmospheric modeling, and observations, J. Geophys. Res., 111, D14306, doi:10.1029/2006JD007118, 2006.

Tan, Q., Chameides, W. L., Streets, D., Wang, T., Xu, J., Bergin, M., and Woo, J.: An evaluation of TRACE-P emission inventories from China using a regional model and chemical measurements, J. Geophys. Res., 109, D22305, doi:10.1029/2004JD005071, 2004.

Tanimoto, H., Sawa, Y., Yonemura, S., Yumimoto, K., Matsueda, H., Uno, I., Hayasaka, T., Mukai, H., Tohjima, Y., Tsuboi, K., and Zhang, L.: Diagnosing recent $\mathrm{CO}$ emissions and ozone evolution in East Asia using coordinated surface observations, adjoint inverse modeling, and MOPITT satellite data, Atmos. Chem. Phys., 8, 3867-3880, 2008,

http://www.atmos-chem-phys.net/8/3867/2008/.

Tang, Y., Carmichael, G. R., Seinfeld, J. H., Dabdub, D., Weber, R. J., Huebert, B., Clarke, A. D., Guazzotti, S. A., Sodeman, D. A., Prather, K. A., Uno, I., Woo, J.-H., Streets, D. G., Quinn, P. K., Johnson, J. E., Song, C.-H., Sandu, A., Talbot, R. W., and Dibb, J. E.: Three-dimensional simulations of inorganic aerosol distributions in east Asia during spring 2001, J. Geophys. Res., 109, D19S23, doi:10.1029/2003JD004201, 2004.

USGS (United States Geological Survey): USGS Minerals Yearbook Volume III. - Area Reports: International, available at: http://minerals.usgs.gov/minerals/pubs/myb.html, 2006.

Uno, I., Carmichael, G. R., Streets, D. G., Tang, Y., Yienger, J. J., Satake, S., Wang, Z., Woo, J.-H., Guttikunda, S., Uematsu, M., Matsumoto, K., Tanimoto, H., Yoshioka, K., and Iida, T.: Regional chemical weather forecasting system CFORS: Model 
descriptions and analysis of surface observations at Japanese island stations during the ACE-Asia experiment, J. Geophys. Res., 108, 8668, doi:10.1029/2002JD002845, 2003a.

Uno, I., Carmichael, G. R., Streets, D., Satake, S., Takemura, T., Woo, J.-H., Uematsu, M., and Ohta, S.: Analysis of surface black carbon distributions during ACE-Asia using a regional-scale aerosol model, J. Geophys. Res., 108, 8636, doi:10.1029/2002JD003252, 2003b.

Uno, I., He, Y., Ohara, T., Yamaji, K., Kurokawa, J.-I., Katayama, M., Wang, Z., Noguchi, K., Hayashida, S., Richter, A., and Burrows, J. P.: Systematic analysis of interannual and seasonal variations of model-simulated tropospheric $\mathrm{NO}_{2}$ in Asia and comparison with GOME-satellite data, Atmos. Chem. Phys., 7, 16711681, 2007, http://www.atmos-chem-phys.net/7/1671/2007/.

van Aardenne, J. A., Carmichael, G. R., Levy, H., Streets, D., and Hordijk, L.: Anthropogenic $\mathrm{NO}_{\mathrm{x}}$ emissions in Asia in the period 1990-2020, Atmos. Environ., 33, 633-646, 1999.

van der A, R. J., Peters, D. H. M. U., Eskes, H., Boersma, K. F., Van Roozendael, M., De Smedt, I., and Kelder, H. M.: Detection of the trend and seasonal variation in tropospheric $\mathrm{NO}_{2}$ over China, J. Geophys. Res., 111, D12317, doi:10.1029/2005JD006594, 2006.

van der A, R. J., Eskes, H. J., Boersma, K. F., van Noije, T. P. C., Van Roozendael, M., De Smedt, I., Peters, D. H. M. U., and Meijer, E. W.: Trends, seasonal variability and dominant $\mathrm{NO}_{\mathrm{x}}$ source derived from a ten year record of $\mathrm{NO}_{2}$ measured from space, J. Geophys. Res., 113, D04302, doi:10.1029/2007JD009021, 2008.

van der Werf, G. R., Randerson, J. T., Giglio, L., Collatz, G. J., Kasibhatla, P. S., and Arellano Jr., A. F.: Interannual variability in global biomass burning emissions from 1997 to 2004, Atmos. Chem. Phys., 6, 3423-3441, 2006, http://www.atmos-chem-phys.net/6/3423/2006/.

van Donkelaar, A., Martin, R. V., Leaitch, W. R., Macdonald, A. M., Walker, T. W., Streets, D. G., Zhang, Q., Dunlea, E. J., Jimenez, J. L., Dibb, J. E., Huey, L. G., Weber, R., and Andreae, M. O.: Analysis of aircraft and satellite measurements from the Intercontinental Chemical Transport Experiment (INTEX-B) to quantify long-range transport of East Asian sulfur to Canada, Atmos. Chem. Phys., 8, 2999-3014, 2008,

http://www.atmos-chem-phys.net/8/2999/2008/.

Wang, Y. X., McElroy, M. B., Wang, T., and Palmer, P. I.: Asian emissions of $\mathrm{CO}$ and $\mathrm{NO}_{\mathrm{X}}$ : Constraints from aircraft and Chinese station data, J. Geophys. Res., 109, D24304, doi:10.1029/2004JD005250, 2004.

Wang, Y. X., McElroy, M. B., Martin, R. V., Streets, D. G., Zhang, Q., and Fu, T.-M.: Seasonal variability of $\mathrm{NO}_{\mathrm{x}}$ emissions over east China constrained by satellite observations: Implications for combustion and microbial sources, J. Geophys. Res., 112, D06301, doi:10.1029/2006JD007538, 2007.

Wang, H., Fu, L., Lin, X., Zhou, Y., and Chen, J.: A bottom-up methodology to estimate vehicle emissions for the Beijing urban area, Sci. Total Environ., 407, 1947-1953, 2009.

Wei, W., Wang, S., Chatani, S., Klimont, Z., Cofala, Z., and Hao, J.: Emission and speciation of non-methane volatile organic compounds from anthropogenic sources in China, Atmos. Environ., 42, 4976-4988, 2008.
Woo, J.-H., Baek, J. M., Kim, J.-W., Carmichael, G. R., Thongboonchoo, N., Kim, S. T., and An, J. H.: Development of a multi-resolution emission inventory and its impact on sulfur distribution for Northeast Asia, Water Air Soil Poll., 148, 259-278, 2003.

Yumimoto, K. and Uno, I.: Adjoint inverse modeling of CO emissions over the East Asian region using four dimensional variational data assimilation, Atmos. Environ., 40, 6836-6845, 2006.

Zhang, L., Jacob, D. J., Boersma, K. F., Jaffe, D. A., Olson, J. R., Bowman, K. W., Worden, J. R., Thompson, A. M., Avery, M. A., Cohen, R. C., Dibb, J. E., Flock, F. M., Fuelberg, H. E., Huey, L. G., McMillan, W. W., Singh, H. B., and Weinheimer, A. J.: Transpacific transport of ozone pollution and the effect of recent Asian emission increases on air quality in North America: an integrated analysis using satellite, aircraft, ozonesonde, and surface observations, Atmos. Chem. Phys., 8, 6117-6136, 2008, http://www.atmos-chem-phys.net/8/6117/2008/.

Zhang, Q., Klimont, Z., Streets, D. G., Huo, H., and He, K.: An anthropogenic PM emission model for China and emission inventory for the year 2001, Prog. Nat. Sci., 16(2), 223-231, 2006, (in Chinese).

Zhang, Q., Streets, D. G., He, K., and Klimont, Z.: Major components of China's anthropogenic primary particulate emissions, Environ. Res. Lett., 2, 045027, doi:10.1088/17489326/2/4/045027, 2007a.

Zhang, Q., Streets, D. G., He, K., Wang, Y., Richter, A., Burrows, J. P., Uno, I., Jang, C. J., Chen, D., Yao, Z., and Lei, Y.: $\mathrm{NO}_{\mathrm{x}}$ emission trends for China, 1995-2004: The view from the ground and the view from space, J. Geophys. Res., 112, D22306, doi:10.1029/2007JD008684, 2007b.

Zhang, Q., Chen, D., Streets, D. G., et al.: Mapping Asia's anthropogenic VOC emissions to multiple chemical mechanisms, in preparation, 2009.

Zhang, Y., Schauer, J. J., Zhang, Y., Zeng, L., Wei, Y., Liu, Y., and Shao, M.: Characteristics of particulate carbon emissions from real-world Chinese coal combustion, Environ. Sci. Technol., 42, 5068-5073, 2008.

Zhao, Y., Wang, S., Duan, L., Lei, Y., Cao, P., and Hao, J.: Primary air pollutant emissions of coal-fired power plants in China: Current status and future prediction, Atmos. Environ., 42, 84428452, 2008.

Zhao, C. and Wang, Y.: Assimilated inversion of $\mathrm{NO}_{\mathrm{x}}$ emissions over east Asia using $\mathrm{OMI} \mathrm{NO}_{2}$ column measurements, Geophys. Res. Lett., 36, L06805, doi:10.1029/2008GL037123, 2009.

Zhao, C., Wang, Y., and Zeng, T.: East China plains: A "basin" of ozone pollution, Environ. Sci. Technol., 43, 1911-1915, 2009.

Zhi, G., Chen, Y., Feng, Y., Xiong, S., Li, J., Zhang, G., Sheng, G., and Fu, J.: Emission characteristics of carbonaceous particles from various residential coal-stoves in China, Environ. Sci. Technol., 42, 3310-3315, 2008. 